Prepared in cooperation with the National Park Service and the Missouri Department of Conservation

\title{
Method Comparisons for Determining Concentrations of Metals in Water Samples Used in Studies of Fish Migratory Histories
}

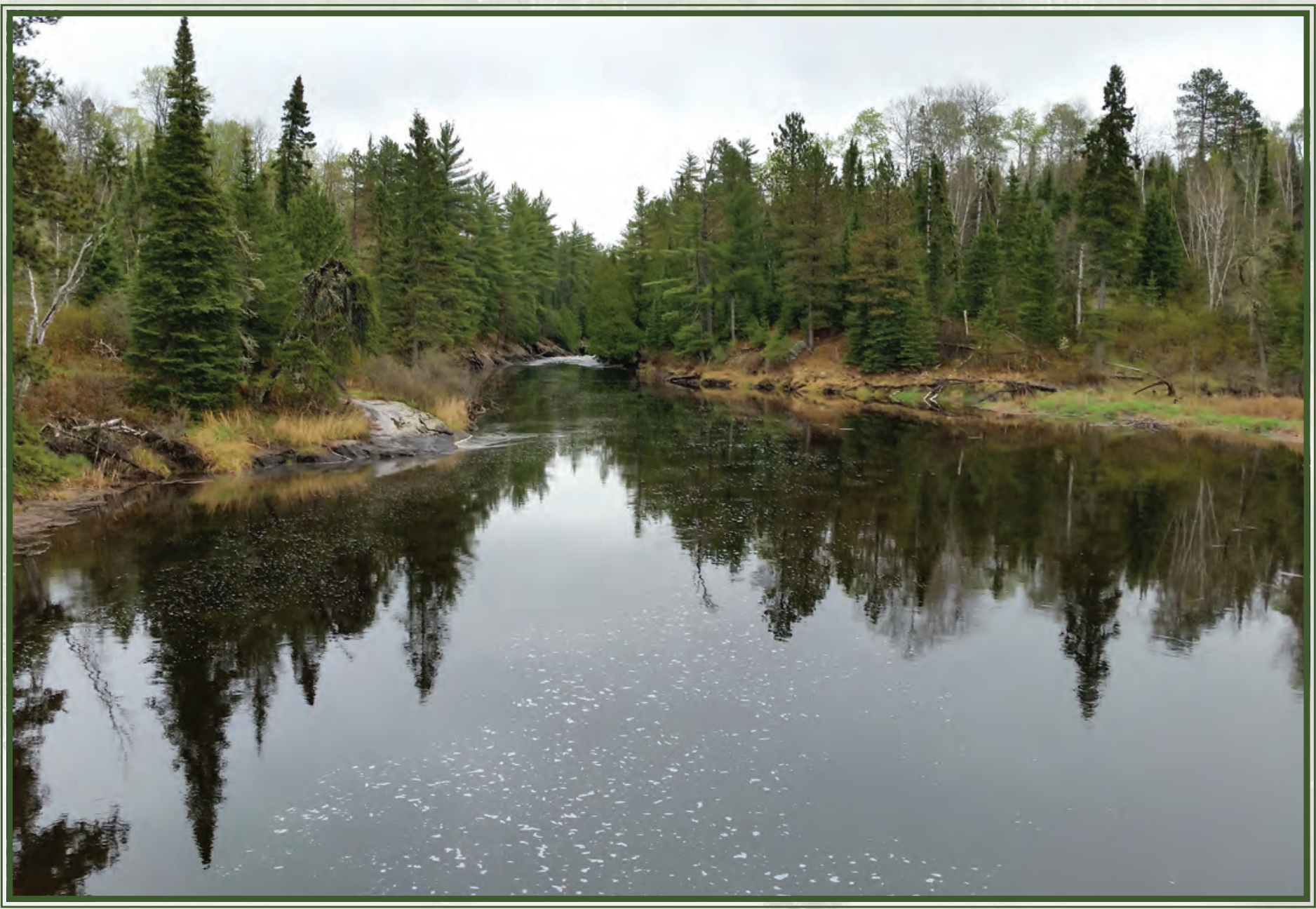

Scientific Investigations Report 2018-5143 
Front cover. Vermilion River, Minnesota, looking downstream towards Vermilion Gorge.

Back cover. St. Croix River at Prescott, Wisconsin, looking upstream.

Photographs by Jeffrey Ziegeweid, U.S. Geological Survey. 


\section{Method Comparisons for Determining Concentrations of Metals in Water Samples Used in Studies of Fish Migratory Histories}

By Jeffrey R. Ziegeweid, Steven J. Zigler, Ryan P. Maki, Byron N. Karns, and Seth A. Love

Prepared in cooperation with the National Park Service and the Missouri Department of Conservation

Scientific Investigations Report 2018-5143 


\title{
U.S. Department of the Interior \\ RYAN K. ZINKE, Secretary
}

\author{
U.S. Geological Survey \\ James F. Reilly II, Director
}

U.S. Geological Survey, Reston, Virginia: 2018

For more information on the USGS - the Federal source for science about the Earth, its natural and living resources, natural hazards, and the environment-visit https://www.usgs.gov or call 1-888-ASK-USGS.

For an overview of USGS information products, including maps, imagery, and publications,

visit https://store.usgs.gov.

Any use of trade, firm, or product names is for descriptive purposes only and does not imply endorsement by the U.S. Government.

Although this information product, for the most part, is in the public domain, it also may contain copyrighted materials as noted in the text. Permission to reproduce copyrighted items must be secured from the copyright owner.

Suggested citation:

Ziegeweid, J.R., Zigler, S.J., Maki, R.P., Karns, B.N., and Love, S.A., 2018, Method comparisons for determining concentrations of metals in water samples used in studies of fish migratory histories: U.S. Geological Survey Scientific Investigations Report 2018-5143, 20 p., https://doi.org/10.3133/sir20185143.

ISSN 2328-0328 (online) 


\section{Acknowledgments}

Funding for the studies described in this report was provided through the Natural Resource Preservation and Water-Quality Partnership cooperative programs between the U.S. Geological Survey and the National Park Service. Claire Kissane, Jaime LeDuc, Greggory Jennings, Heather Clingman, and Halie Hajek of the National Park Service assisted with the collection of waterquality samples. Dr. Quinton Phelps of West Virginia University assisted with study design and coordinated filtration of water samples for laboratory analyses. Dr. Alan Shiller of the University of Southern Mississippi conducted laboratory analyses of grab water samples.

Several U.S. Geological Survey personnel are acknowledged for contributions to this report. Russ Buesing, Katie Allenson, Erik Lahti, Aliesha Krall, and Lindsay Hastings assisted with the collection and processing of water-quality samples. Erin Coenen created the map figure, and Jared Trost helped create graph figures used in the report. Brent Knights provided helpful information about related U.S. Geological Survey studies in the St. Croix and Mississippi Rivers. Heather Krempa and Dr. Richard Kiesling are acknowledged for providing technical reviews of this report. 



\section{Contents}

Acknowledgments ……...................................................................................................................

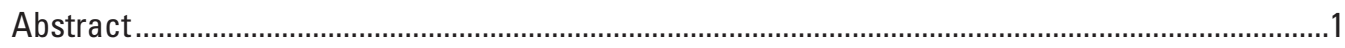

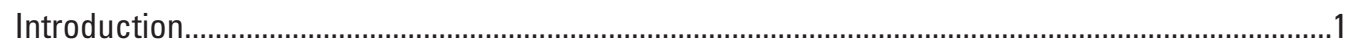

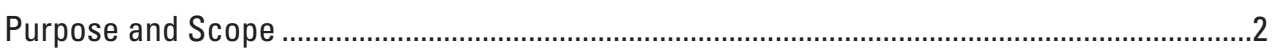

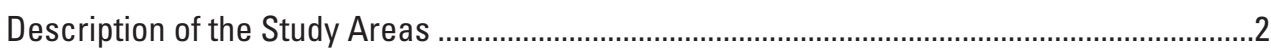

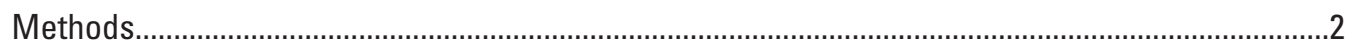

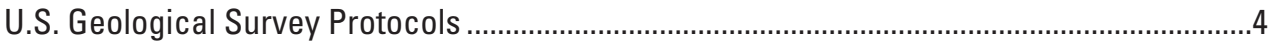

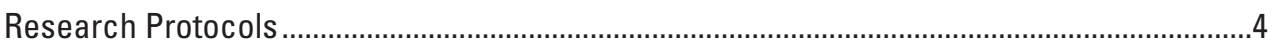

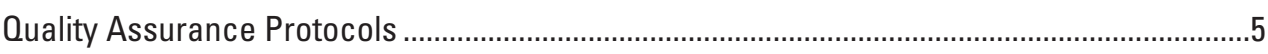

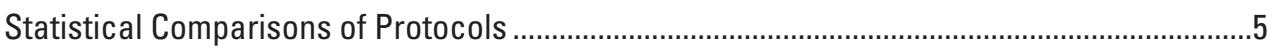

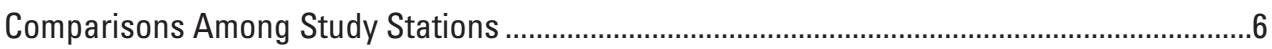

Comparisons of U.S. Geological Survey and Research Protocols ....................................................

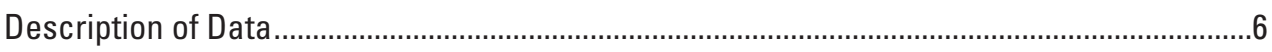

Quality Assurance Comparisons .................................................................................................

Statistical Comparisons of Protocols ..................................................................................

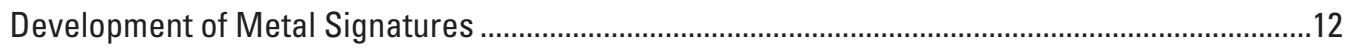

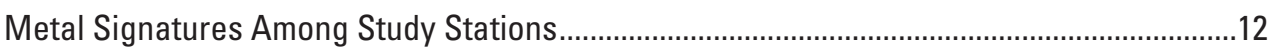

Comparisons to Previously Collected Metal Concentration Data .........................................15

Insights from Method and Station Comparisons ...............................................................16

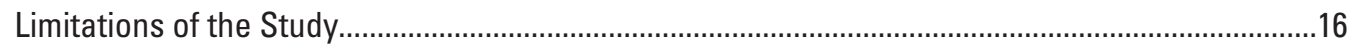

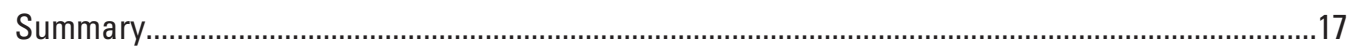

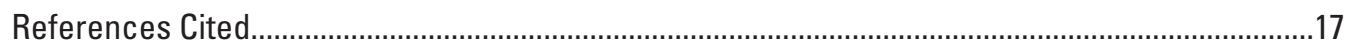

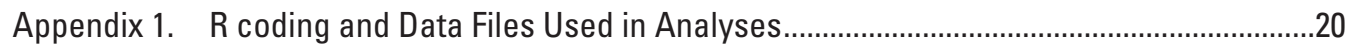

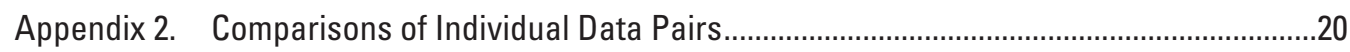

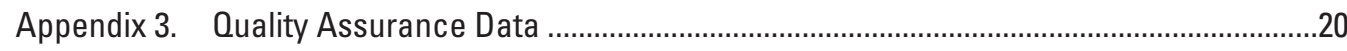

\section{Figures}

1. Maps of the two study areas described in this report .....................................................

2. Scatterplots and trendlines from simple linear regression analyses comparing relations between results obtained using U.S. Geological Survey and research protocols

3. Graphs showing median values and measured ranges for ratios of strontium to calcium obtained using U.S. Geological Survey and research protocols for stations in the St. Croix National Scenic Riverway and Mississippi National River and Recreation Area study area, and the Voyageurs National Park study area

4. Graphs showing median values and measured ranges for ratios of barium to calcium obtained using U.S. Geological Survey and research protocols for stations in the St. Croix National Scenic Riverway and Mississippi National River and Recreation Area study area, and the Voyageurs National Park study area.. 
5. Graphs showing median values and measured ranges for ratios of strontium to calcium and barium to calcium obtained using U.S. Geological

Survey protocols for stations in the St. Croix National Scenic Riverway and Mississippi National River and Recreation Area study area, and the Voyageurs National Park study area.

6. Graphs showing median values and measured ranges for ratios of strontium to calcium and barium to calcium obtained using research protocols for stations in the St. Croix National Scenic Riverway and Mississippi National River and Recreation Area study area, and the Voyageurs National Park study area.

\section{Tables}

1. Metal concentrations obtained using research protocols for stations in the St. Croix, Mississippi, Minnesota, and Chippewa Rivers; map numbers reference stations shown in figure 1

2. Metal concentrations obtained using research protocols for stations in the five lakes and six major tributaries that compose the Namakan Reservoir system; map numbers reference stations shown in figure 1 .

3. Results of one-sample $t$-tests and 95-percent confidence intervals used to determine whether mean differences in results obtained using U.S. Geological Survey and research protocols were significantly different from zero.

4. Absolute percent difference data used to compare metal results obtained using U.S. Geological Survey and research protocols

5. Results of simple linear regression analyses used to determine whether relations between results obtained using U.S. Geological Survey and research protocols are significant

\section{Conversion Factors}

International System of Units to U.S. customary units

\begin{tabular}{lcl}
\hline \multicolumn{1}{c}{ Multiply } & By & \multicolumn{1}{c}{ To obtain } \\
\hline kilometer $(\mathrm{km})$ & Length & mile (mi) \\
meter $(\mathrm{m})$ & 0.6214 & feet $(\mathrm{ft})$ \\
\hline & 0.3048 & \\
\hline liter $(\mathrm{L})$ & Volume & cubic inch $\left(\mathrm{in}^{3}\right)$ \\
\hline & 61.02 & \\
\hline gram $(\mathrm{g})$ & Mass & ounce $(\mathrm{oz})$ \\
\hline
\end{tabular}

Temperature in degrees Celsius $\left({ }^{\circ} \mathrm{C}\right)$ may be converted to degrees Fahrenheit $\left({ }^{\circ} \mathrm{F}\right)$ as

$$
{ }^{\circ} \mathrm{F}=\left(1.8 \times{ }^{\circ} \mathrm{C}\right)+32
$$

Temperature in degrees Fahrenheit $\left({ }^{\circ} \mathrm{F}\right)$ may be converted to degrees Celsius $\left({ }^{\circ} \mathrm{C}\right)$ as

$$
{ }^{\circ} \mathrm{C}=\left({ }^{\circ} \mathrm{F}-32\right) / 1.8 \text {. }
$$




\title{
Datum
}

Vertical coordinate information is referenced to the North American Vertical Datum of 1988 (NAVD 88).

Horizontal coordinate information is referenced to the North American Datum of 1983 (NAD 83).

Altitude, as used in this report, refers to distance above the vertical datum.

\section{Abbreviations}

\author{
$\mathrm{Ba}: \mathrm{Ca}$ ratio of barium to calcium, expressed as micromoles per mole ( $\mu \mathrm{mol} / \mathrm{mol})$ \\ BOS Branch of Quality Systems \\ csv comma-separated value \\ ICPAES inductively coupled plasma atomic emission spectroscopy \\ ICPMS inductively coupled plasma mass spectrometry \\ MISS Mississippi National River and Recreation Area \\ NPS National Park Service \\ NWIS National Water Information System \\ NWQL National Water Quality Laboratory \\ $R^{2} \quad$ coefficient of determination \\ SACN St. Croix National Scenic Riverway \\ $\mathrm{Sr}: \mathrm{Ca}$ ratio of strontium to calcium, expressed as micromoles per mole $(\mu \mathrm{mol} / \mathrm{mol})$ \\ SRS standard reference sample \\ USGS U.S. Geological Survey \\ USM University of Southern Mississippi \\ VOYA Voyageurs National Park
}





\title{
Method Comparisons for Determining Concentrations of Metals in Water Samples Used in Studies of Fish Migratory Histories
}

\author{
By Jeffrey R. Ziegeweid, ${ }^{1}$ Steven J. Zigler, ${ }^{1}$ Ryan P. Maki, ${ }^{2}$ Byron N. Karns, ${ }^{2}$ and Seth A. Love ${ }^{3}$
}

\section{Abstract}

Signatures developed from metal concentrations in water and fish bony structures can be used to demonstrate migration of individual fish between connected water bodies. The U.S. Geological Survey (USGS), in cooperation with the National Park Service and the Missouri Department of Conservation, compared two protocols for collecting and analyzing water samples for concentrations of several metals commonly used to develop metal signatures. In 2015, paired seasonal water samples were collected in two study areas incorporating three National Park Service units; paired water samples were collected using USGS protocols and simpler research protocols. Metal concentrations obtained using USGS and research protocols were compared using $t$-tests, percent differences, and simple linear regression analyses. Graphical plots of median values and measured ranges were used to compare ratios of strontium to calcium $(\mathrm{Sr}: \mathrm{Ca})$ and barium to calcium $(\mathrm{Ba}: \mathrm{Ca})$ obtained using the different protocols among individual stations within the two study areas. For stations on the Mississippi and St. Croix Rivers, ranges in concentrations of calcium, barium, and strontium (obtained using USGS protocols) were compared between samples collected from 1995 through 2012 and samples collected in this study. Comparisons were used to evaluate the long-term stability of metal concentrations in the environment.

Collectively, results presented in this report demonstrated that research protocols provided metal concentration data that were similar to data obtained using USGS protocols for all compared metals except manganese. Holding times of 6-33 weeks prior to filtration and analyses for samples collected using research protocols may have caused greater changes in manganese concentrations compared to other metals. Strontium, barium, and calcium are the metals most commonly used in studies of fish migration, and concentrations of these metals were similar using different protocols. However,

${ }^{1}$ U.S. Geological Survey.

${ }^{2}$ National Park Service.

${ }^{3}$ Illinois Natural History Survey. rivers within each study area were more easily distinguished from each other using metal concentration data obtained using USGS protocols compared to data obtained using research protocols. Information presented in this report can be used to develop studies that use identified metal signatures in connected water bodies and bony fish structures to demonstrate fish migration.

\section{Introduction}

Tracking and managing populations of migratory fishes can be challenging and expensive, but chemical techniques have been developed to maximize information from routine fish surveys. As fish grow, metals that substitute for calcium, such as strontium and barium, are absorbed into bony structures used for age determination, such as otoliths and pectoral fin rays (Elsdon and others, 2008). Concentrations of metals accumulate in fish bony structures in proportion to the concentrations of the metals in the surrounding water. Cross sections of fish bony structures can be analyzed for metals using laser ablation spectrometry techniques (Crook and Gillanders, 2006; Elsdon and Gillanders, 2006; Elsdon and others, 2008; Humston and others, 2010; Smith and Whitledge, 2010; Hayden and others, 2011; Phelps and others, 2012). In addition, metal concentrations measured in water samples can be used to develop unique signatures for individual water bodies. Statistical relations between concentrations of metals in water and pectoral fin rays have been used to demonstrate migrations of individual fish between water bodies that have distinct metal signatures (Crook and Gillanders, 2006; Elsdon and Gillanders, 2006; Elsdon and others, 2008; Humston and others, 2010; Smith and Whitledge, 2010; Hayden and others, 2011; Phelps and others, 2012).

The U.S. Geological Survey (USGS) has developed and published protocols for collecting representative water samples that integrate the depth, width, and velocity of the river channel (U.S. Geological Survey, variously dated). The term "USGS protocols" will hereafter be used to refer to USGS methods for collecting, processing, and analyzing water 
samples for metals specified in this report. Integrated water samples result in metal concentration data that accurately represent concentrations throughout the entire river cross-section. However, USGS protocols are time and labor intensive and require specialized training and equipment. Therefore, researchers often use grab samples and simpler methods of filtration and analysis to characterize metal concentrations in rivers for comparison to concentrations in fish bony parts used to infer migration between water bodies (Crook and Gillanders, 2006; Humston and others, 2010; Smith and Whitledge, 2010; Hayden and others, 2011; Phelps and others, 2012). The term "research protocols" will hereafter be used to refer to research methods for collecting, processing, and analyzing water samples for metals as specified in this report.

This report was prepared by the USGS in cooperation with the National Park Service (NPS) and the Missouri Department of Conservation and describes the results of two studies that incorporate three NPS units. In these studies, water samples and lake sturgeon (Acipenser fulvescens) pectoral fin rays were analyzed for metal concentrations to evaluate migratory patterns of lake sturgeon and provide background information about lake sturgeon populations prior to effects of potential environmental and management stressors previously identified for each study area. However, this report only presents comparisons of metal concentration data for water samples collected and analyzed using USGS protocols and research protocols that are used more commonly in studies of fish migration (Shiller, 2003; Phelps and others, 2012). In addition, this report provides comparisons of metal signatures among several stations within each studied NPS unit.

\section{Purpose and Scope}

The purposes of this report are to (1) provide metal concentration data that did not previously exist for waters of the Namakan Reservoir system, (2) compare metal concentrations obtained using two different protocols, and (3) contrast commonly used metal signatures among stations in two study areas. The scope of this report is limited to the study areas defined in the next section of the report. However, field, laboratory, and data analysis techniques presented in this report could be applied in similar studies of other aquatic systems.

\section{Description of the Study Areas}

This report combines results from two study areas. The first study area included stations within the St. Croix National Scenic Riverway (SACN) and Mississippi National River and Recreation Area (MISS) NPS units. The St. Croix National Scenic Riverway includes the St. Croix River from Gordon Dam (not shown) to the confluence with the Mississippi River at Prescott, Wisconsin (fig. 1). Also included in the St. Croix National Scenic Riverway are the last 100 miles of the Namekagon River, which is the primary tributary to the upper St. Croix River (fig. 1). The Mississippi National River and
Recreation Area includes a 72-mile stretch of the Mississippi River, starting with the confluence of the Crow and Mississippi Rivers and ending at approximately river mile 808 (not shown) on the Mississippi River (fig. 1). In addition, stations on the Minnesota River near Jordan, Minnesota (USGS station 05330000; map number 7, table 1, fig. 1) and the Chippewa River at Durand, Wis. (USGS station 05369500; map number 8 , table 1, fig. 1) were included in the first study area (fig. 1). Hereafter, this study area will be referred to as the "SACN-MISS" study area.

The second study area included stations within the five lakes that compose Namakan Reservoir and the six major tributaries to Namakan Reservoir that historically supported sturgeon reproduction (fig. 1; Kallemeyn and others, 2003; Shaw, 2010; Shaw and others, 2012; Shaw and others, 2013). The five lakes composing Namakan Reservoir include Little Vermilion, Crane, Sand Point, Namakan, and Kabetogama Lakes. The six major tributaries to Namakan Reservoir include the Loon, Vermilion, Redhorse, Namakan, Moose, and Ash Rivers. Collectively, the five lakes and six major tributaries will be referred to as "the Namakan Reservoir system" in this report.

The Namakan Reservoir system is a complex, internationally shared waterway (fig. 1; Kallemeyn and others, 2003). Kabetogama Lake, Ash River, Moose River, and Vermilion River are contained within the United States, and all but the Vermilion River flow through the Voyageurs National Park NPS unit. The Namakan and Redhorse Rivers are contained completely within Ontario, Canada. Namakan, Sand Point, and Little Vermilion Lakes are border lakes. The U.S. portions of Namakan and Sand Point Lakes are part of the Voyageurs National Park NPS unit, and the U.S. portion of Little Vermilion Lake is part of the Boundary Waters Canoe Area Wilderness. Finally, the Loon River forms the border between the United States and Canada at the southeastern end of the study area. Water in the Namakan Reservoir system flows north into Rainy Lake, with most of the water entering Rainy Lake through dams at Kettle and Squirrel Falls on Namakan Lake (fig. 1). A small amount of water enters Rainy Lake from Kabetogama Lake through an outlet at Gold Portage (fig. 1). During high water conditions, water occasionally flows from Namakan Lake to Rainy Lake through an outlet at Bear Portage (fig. 1). Hereafter, the second study area will be referred to as the "VOYA" study area.

\section{Methods}

The "Methods" section is divided into five subsections. The first subsection describes the USGS protocols used to collect, process, and analyze water samples for metal concentrations. The second subsection describes the research protocols used to collect, process, and analyze water samples for metal concentrations. The third subsection describes quality assurance protocols for USGS and research protocols. The fourth 


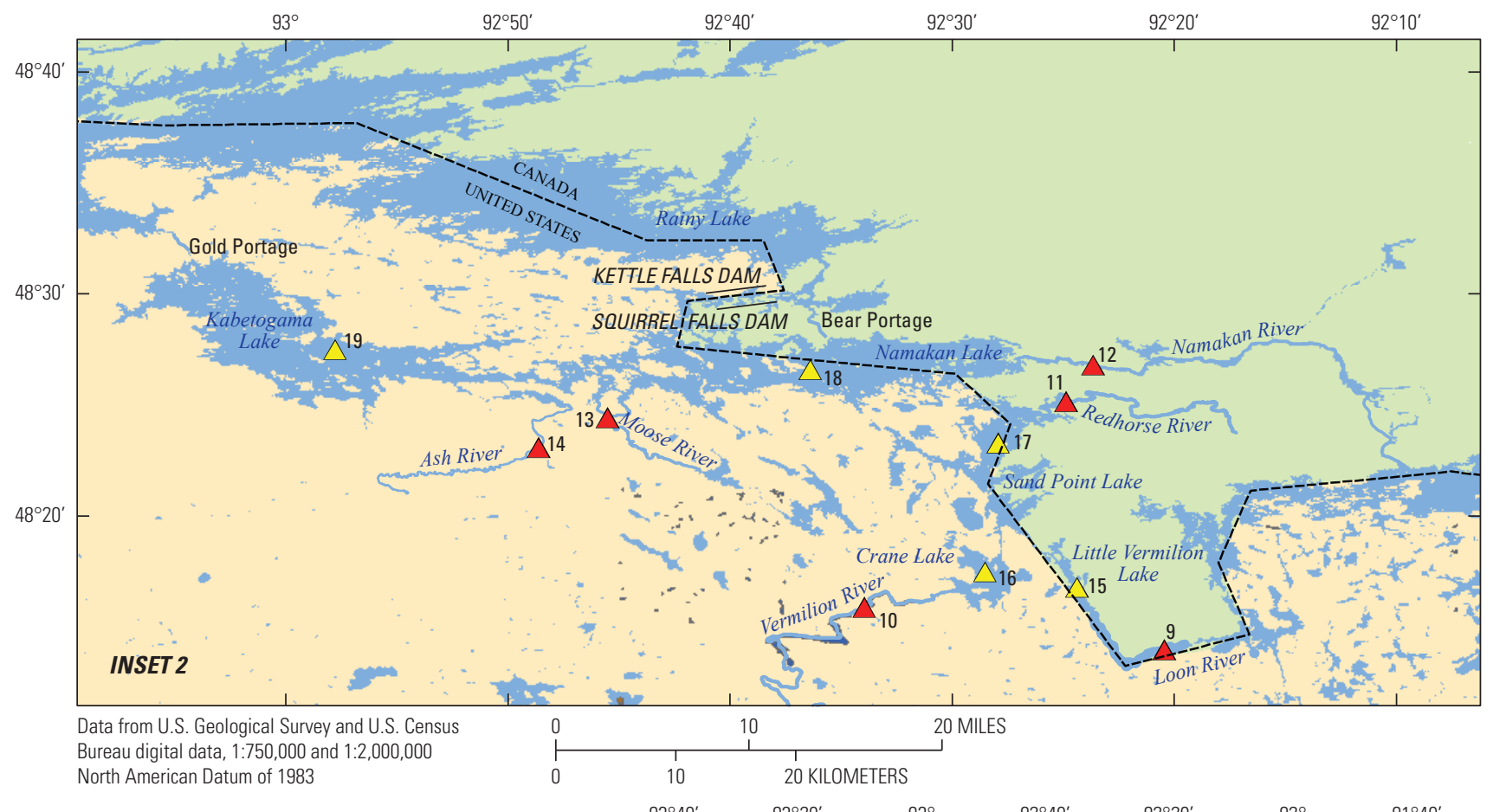

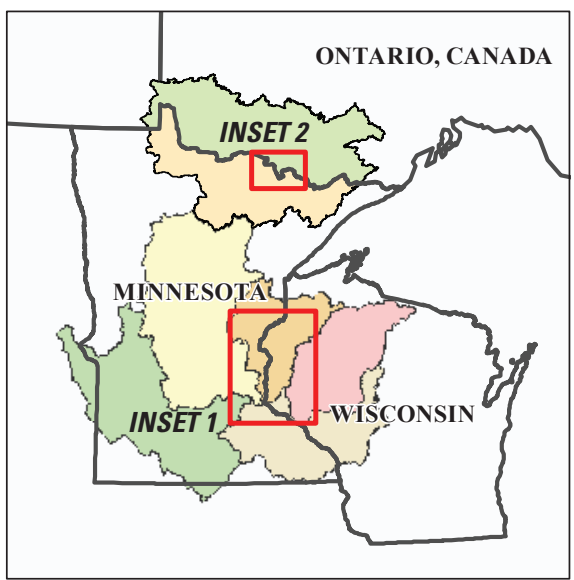

EXPLANATION

River basin

Rainy River (Canada)

Rainy River (United States)

Chippewa River

Minnesota River

Mississippi River headwaters

St. Croix River

Upper Mississippi-Black-Root Rivers

River site (tables 1 and 2)

$1 \triangle$ U.S. Geological Survey (USGS) and research protocols

8 Research protocols only

${ }^{16} \triangle \quad$ Lake site (tables 1 and 2) — USGS and research protocols

Figure 1. The two study areas described in this report.

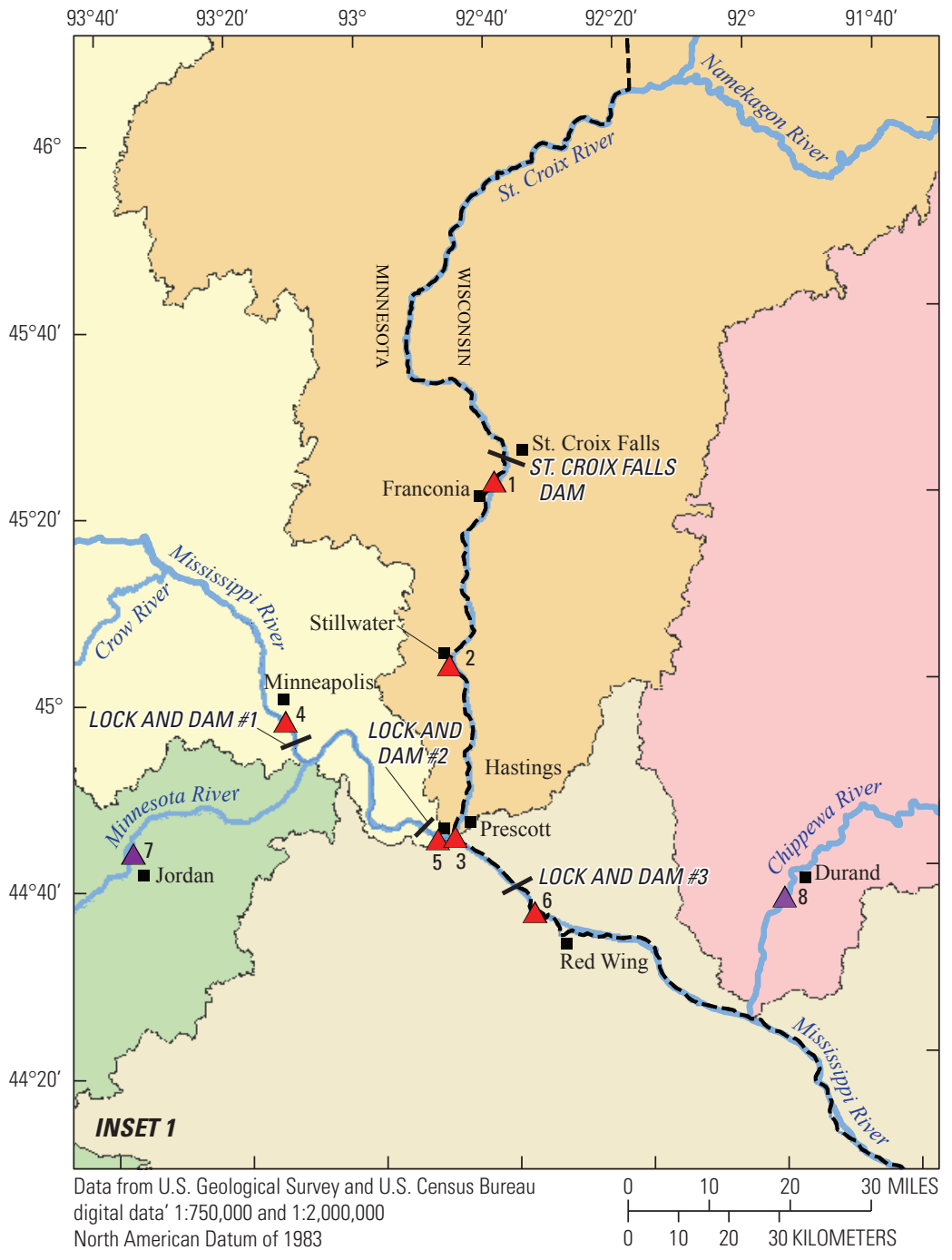


subsection describes the statistical analyses used to compare metal concentrations obtained using the two protocols. The final section describes the analyses used to compare metal signatures among stations within the two study areas.

\section{U.S. Geological Survey Protocols}

Seasonal water samples were collected at each station using USGS protocols (U.S. Geological Survey, variously dated). In the SACN-MISS study area, water samples were collected in the spring, summer, and fall of 2015, and USGS protocols were not used to collect samples from stations on the Chippewa (map number 8) and Minnesota (map number 7) Rivers. In the VOYA study area, water samples were collected only in the spring and fall of 2015. Trained USGS personnel collected the samples using USGS protocols.

Water samples were collected at all river stations by using the equal-width increment method (U.S. Geological Survey, variously dated). Prior to collecting water samples, streamflows were measured at the sampling cross section with an acoustic Doppler current profiler (Mueller and others, 2013). Depth, width, and velocity data obtained from acoustic Doppler current profiler measurements were used to select appropriate equipment for collecting a sample that integrated the entire vertical water column at each sampling point within the cross section. Average stream velocities were less than 1.5 feet per second, which is low enough that non-isokinetic samples were sufficient (U.S. Geological Survey, variously dated). For lake stations in the VOYA study area, collected water samples integrated the top 5 meters of the water column at a single location in the lake.

For field sample collections, protocols were selected to match existing sampling at USGS station 05331580 that is part of the USGS National Water Quality Assessment (NAWQA), which includes analysis of strontium. A weighted-bottle sampler with a baked, 1-liter amber glass bottle was used to collect samples at all stations. A fresh bottle was used at all sampling locations, and the bottle was rinsed twice with native water prior to filling. Water was collected at 5 equal width increments in the river cross section. The weighted bottle sampler was lowered slowly and then was raised slowly just before touching the river bottom. The bottle filled slowly, collecting an integrated sample from throughout the water column.

Water samples collected within each cross section were composited in a clean churn for filtration and laboratory analysis (U.S. Geological Survey, variously dated). Composited samples were filtered, acidified, chilled on ice, and shipped for analyses within 6 hours of sample collection. Sample bottles for each station consisted of 1 raw unfiltered bottle, 1 filtered unacidified bottle, 1 filtered acidified bottle, and 1 alkalinity sample. Alkalinity titrations were done in the laboratory at the USGS office in Mounds View, Minnesota (U.S. Geological Survey, variously dated). All other sample bottles were shipped to the USGS National Water Quality Laboratory (NWQL). Samples were received by the NWQL within
24 hours of sample collection. Composited water samples were analyzed for barium, calcium, chloride, fluoride, iron, magnesium, manganese, potassium, silica, sodium, strontium, sulfate, and total dissolved solids (NWQL schedule 2701, lab codes 641 and 652; Fishman, 1993) using inductively coupled plasma atomic emission spectrometry (ICPAES).

\section{Research Protocols}

Grab samples were collected in the spring, summer, and fall of 2015 at each station in both study areas. In the SACN-MISS study area, all grab samples were collected by USGS personnel. In the VOYA study area, spring and fall grab samples were collected by USGS personnel; summer grab samples were collected by NPS personnel. Grab samples were collected by dipping 1-liter polypropylene bottles below the water surface at the lake station or center of the stream cross section. Prior to sampling, bottles were cleaned with phosphate-free soap, rinsed with tap water, and rinsed with deionized water. Furthermore, bottles were rinsed twice with native water at field sites prior to sample collection. Clean nitrile gloves were worn during grab sample collections to minimize sample contamination. Sample collectors made efforts to select sampling locations that would help minimize debris and flocculent materials that could bias results. Grab samples were chilled on ice immediately following sample collection.

In addition to stations on the St. Croix and Mississippi Rivers, the SACN-MISS study area included stations on the Minnesota and Chippewa Rivers (fig. 1). Seasonal (spring, summer, fall) grab samples were collected by USGS personnel in 2015 at stations on the Minnesota (map number 7) and Chippewa (map number 8) Rivers. Grab samples were collected at these stations because previous telemetry studies indicated that lake sturgeon occasionally migrate from the Mississippi River to the Minnesota and Chippewa Rivers (Joel Stiras, Minnesota Department of Natural Resources, oral commun., 2014). Grab samples from these stations were used to determine whether metal signatures in water from the Minnesota and Chippewa Rivers can be distinguished from metal signatures in water from the St. Croix and Mississippi Rivers.

Grab samples were filtered through 0.45 -micron syringe filters and analyzed according to methods outlined by Shiller (2003), with one exception. Methods in Shiller (2003) include immediate filtering of samples during collection, but in this study, samples were chilled and stored for 6-33 weeks prior to filtration, acidification and analysis. Samples were filtered and analyzed for metals using inductively coupled plasma mass spectrometry (ICPMS) by staff from the University of Southern Mississippi (USM); the laboratory at USM is lab number 390 in the USGS Branch of Quality Systems (BQS) database (Dr. Alan Shiller, University of Southern Mississippi, written commun., 2015; U.S. Geological Survey, 2017a). Samples were analyzed for barium, calcium, lithium, magnesium, manganese, sodium, and strontium. 


\section{Quality Assurance Protocols}

During each seasonal sampling event, 1 replicate sample and 1 blank sample were collected from each study area using USGS protocols. Blank samples consisted of rinsing and filling field bottles with certified inorganic blank water, filling appropriate sample bottles with unfiltered blank water, filtering the blank water, and filling appropriate sample bottles with the filtered blank water (NWQL schedule 2701, lab codes 641 and 652; Fishman, 1993; U.S. Geological Survey, variously dated). The NWQL also participates in the BQS standard reference sample (SRS) project and analyzes SRS samples in the spring and fall of every year (laboratory number 1; U.S. Geological Survey, 2017a). Spring 2015 and Fall 2015 SRS samples were used to compare measured and known SRS values because collected water samples were analyzed in the summer and fall of 2015. Finally, 5-year historical laboratory performance data for the NWQL can be downloaded from the BQS website (laboratory number 1; https://bqs.usgs.gov/; U.S. Geological Survey, 2017a).

During each seasonal sampling event, 1 replicate sample and 1 blank sample also were collected from each study area using research protocols. However, the blank sample collected from the SACN-MISS study area in the spring of 2015 leaked during shipping and could not be analyzed. Blank samples consisted of rinsing and filling field bottles with certified inorganic blank water, storing blank samples chilled along with environmental samples, and shipping blank samples to the laboratory at USM for filtration, acidification, and analysis (Shiller, 2003). In addition, instrument drift was monitored by running check standards and blanks every $8-10$ samples. Furthermore, an internal reference sample referred to as "LFT3" (Dr. Alan Shiller, University of Southern Mississippi, written commun., 2016) was analyzed to further determine the accuracy of the concentrations obtained by USM. The LFT3 internal standard is a long-term quality control sample that previously was compared to certified reference materials. The laboratory at USM also participates in the BQS standard reference sample (SRS) project and analyzes SRS samples in the spring and fall of every year (U.S. Geological Survey, 2017a). Fall 2015 SRS samples were used to compare measured and known SRS values because collected water samples were analyzed in fall 2015. Finally, 5-year historical laboratory performance data for the laboratory at USM can be downloaded from the BQS website (laboratory number 390; https://bqs.usgs.gov/; U.S. Geological Survey, 2017a).

Quality assurance data for both protocols were analyzed using percent differences and relative percent differences. Relative percent differences of metal concentrations in replicate samples were calculated using the following equation:

Relative Percent Difference $=\frac{A B S\left(C_{\text {replicate }}-C_{\text {regular }}\right)}{\left(\frac{C_{\text {replicate }}+C_{\text {regular }}}{2}\right)} \times 100$, where

$$
\begin{gathered}
A B S \quad \begin{array}{c}
\text { is the absolute value of the difference in } \\
\text { concentrations; }
\end{array} \\
C_{\text {replicate }} \quad \begin{array}{c}
\text { is the concentration measured in the replicate } \\
\text { sample; and }
\end{array} \\
C_{\text {regular }} \quad \begin{array}{c}
\text { is the concentration measured in the regular } \\
\text { sample. }
\end{array}
\end{gathered}
$$

For research protocols, measured concentrations of the LFT3 internal standard were compared to known values using the following equation:

$$
\text { Percent Difference }=\frac{C_{\text {measured }}-C_{\text {known }}}{\left(C_{\text {known }}\right)} \times 100,
$$

where

$C_{\text {measured }} \quad$ is the measured concentration of LFT3; and

$C_{\text {known }}$ is the known concentration of LFT3.

\section{Statistical Comparisons of Protocols}

Statistical analyses were conducted to compare concentrations for six metals common to both protocols: barium, calcium, magnesium, manganese, sodium, and strontium. In addition, statistical analyses were conducted on ratios of barium to calcium $(\mathrm{Ba}: \mathrm{Ca})$ and strontium to calcium $(\mathrm{Sr}: \mathrm{Ca})$ in collected water samples; ratios are expressed in units of micromoles of barium or strontium to moles of calcium. These ratios commonly are measured in water samples and in fish bony structures used for determining fish ages. Ratios of metals in water and cross sections of fish bony structures used to determine fish ages can be compared to demonstrate migrations between water bodies with different chemical signatures (Crook and Gillanders, 2006; Elsdon and Gillanders, 2006; Elsdon and others, 2008; Humston and others, 2010; Smith and Whitledge, 2010; Hayden and others, 2011; Phelps and others, 2012).

Several statistical analyses were used to compare metal concentration data collected using the two protocols. Datasets were evaluated for normality using Shapiro-Wilk tests and the probability plot correlation coefficient command (ppcc.test) in the smwrStats package for the R statistical environment (Venables and others, 2010; Lorenz, 2014). Samples collected using research protocols that did not have a paired sample collected using USGS protocols were excluded from these statistical analyses. Paired individual samples initially were compared using differences (research concentration minus USGS concentration). For each metal, the sample population of differences was evaluated with a one-sample $t$-test to determine whether observed differences were significantly different from zero (Ott and Longnecker, 2010). A two-tailed test was used to calculate 95-percent confidence intervals around the mean difference for each metal. 
For each metal, percent difference in concentrations measured using USGS and research protocols were computed using the following equation:

$$
\text { Percent Difference }=\frac{C_{\text {research }}-C_{U S G S}}{\left(C_{U S G S}\right)} \times 100,
$$

where

$$
\begin{array}{cc}
C_{\text {research }} & \text { is the concentration obtained by ICPMS using } \\
\text { research protocols; and } \\
C_{U S G S} & \text { is the concentration obtained by ICPAES } \\
\text { using USGS protocols. }
\end{array}
$$

Positive and negative percent differences indicate that concentrations measured using research methods were greater than and less than concentrations measured using USGS methods, respectively. Mean absolute values with 95-percent confidence intervals of percent differences (hereafter referred to as "absolute percent differences") were computed for the sample population of each metal compared between USGS and research protocols to determine the average deviation of the research concentration from the USGS concentration.

Simple linear regression analyses were used to examine the relations between concentration data collected using USGS and research protocols. Concentrations obtained using research protocols were the explanatory variables in all regression analyses. Concentrations obtained using USGS protocols were the response variables in all regression analyses. A type I error level $(\alpha)$ of 0.05 was used to evaluate the significance of all statistical analyses. All analyses were completed using standard commands available in the base version of the $\mathrm{R}$ statistical environment (version 3.4.0; Venables and others, 2010). Scatterplots were created using the smwrGraphs package in the R statistical environment (Venables and others, 2010; Lorenz and Diekoff, 2017). Examples of R codes used in these analyses are presented in appendix 1. Regression analyses were not used to develop predictive surrogate relations.

\section{Comparisons Among Study Stations}

Sample sizes were too small to compare $\mathrm{Sr}: \mathrm{Ca}$ and $\mathrm{Ba}: \mathrm{Ca}$ among stations within study areas using common statistical analyses. Therefore, graphical comparisons of median values and ranges were used to compare $\mathrm{Sr}: \mathrm{Ca}$ and $\mathrm{Ba}: \mathrm{Ca}$ values among stations within each study area. First, median values and ranges obtained using USGS and research protocols were plotted together for each station in the two study areas, with separate figures for $\mathrm{Sr}: \mathrm{Ca}$ and $\mathrm{Ba}: \mathrm{Ca}$. Next, $\mathrm{Sr}: \mathrm{Ca}$ and $\mathrm{Ba}: \mathrm{Ca}$ values were plotted together for individual stations, with separate figures describing results obtained using USGS and research protocols. Figures are further divided into separate plots for each study area. In presented figures, data bars without error bars indicate that the range of measured values consisted of one value, either because only one sample was collected or because multiple samples resulted in the same value.
For stations in the SACN-MISS study area, concentrations of calcium, barium, and strontium measured in this study were compared to concentrations measured prior to this study to evaluate the stability of metal concentrations over time. Only data collected using USGS protocols were compared, and data were pooled for Mississippi and St. Croix River stations because few data points were available. Pre-study data used in comparisons were collected between 1995 and 2012; samples collected from 1972 through 1981 were excluded because of concerns about data comparability related to analytical technologies and method detection limits. All pre-study data used in comparisons are publicly available through the National Water Information System (NWIS; U.S. Geological Survey, 2017b).

\section{Comparisons of U.S. Geological Survey and Research Protocols}

This section of the report will be broken into three subsections. The first subsection identifies the location of the datasets compared in statistical analyses, as well as the units corresponding to the variables being compared. The second subsection describes the results of quality assurance analyses for USGS and research protocols. The final subsection describes the results of statistical analyses comparing metal concentrations obtained using USGS and research protocols.

\section{Description of Data}

Metal concentration data obtained using research protocols are presented in tables 1 and 2 of this report. Data collected in the SACN-MISS study area are presented in table 1, and data collected in the VOYA study area are presented in table 2. Concentrations of barium, lithium, manganese, and strontium are presented in units of micrograms per liter. Concentrations of calcium, magnesium, and sodium are presented in units of milligrams per liter.

Metal concentration data obtained by using USGS protocols can be accessed through the USGS NWIS (U.S. Geological Survey, 2017b) using station numbers presented in tables 1 and 2 (U.S. Geological Survey, 2017b). In addition, concentration data from NWIS for six metals common to both the USGS protocols and research protocols are included in table 2.1 of appendix 2. Streamflow measurement data associated with each collected river water sample also are available in NWIS using station numbers presented in tables 1 and 2. Summer results presented in table 2 cannot be compared to results in NWIS because only grab samples (research protocols) were collected in the VOYA study area. Furthermore, the station on the Moose River (USGS station 05129160, map number 13 , table 2 , fig. 1) could not be accessed during spring sampling. A grab sample (research protocols) was collected by NPS staff three weeks later, but a corresponding sample 
Table 1. Metal concentrations obtained using research protocols for stations in the St. Croix, Mississippi, Minnesota, and Chippewa Rivers; map numbers reference stations shown in figure 1.

[Ba, barium; $\mu \mathrm{g} / \mathrm{L}$, microgram per liter; Li, lithium; Mn, manganese; Sr, strontium; Ca, calcium; mg/L, milligram per liter; Mg, magnesium; $\mathrm{Na}$, sodium; nr, near; MN, Minnesota; WI, Wisconsin; R., River; Ave., Avenue; L\&D \#, Lock and Dam number]

\begin{tabular}{|c|c|c|c|c|c|c|c|c|c|c|c|c|}
\hline $\begin{array}{c}\text { Map } \\
\text { number }\end{array}$ & $\begin{array}{c}\text { Site } \\
\text { number }\end{array}$ & Site name & Season & Date & Time & $\begin{array}{c}\mathrm{Ba} \\
(\mu \mathrm{g} / \mathrm{L})\end{array}$ & $\begin{array}{c}\mathrm{Li} \\
(\mu \mathrm{g} / \mathrm{L})\end{array}$ & $\begin{array}{c}\mathrm{Mn} \\
(\mu \mathrm{g} / \mathrm{L})\end{array}$ & $\begin{array}{c}\mathrm{Sr} \\
(\mu \mathrm{g} / \mathrm{L})\end{array}$ & $\begin{array}{c}\mathrm{Ca} \\
(\mathrm{mg} / \mathrm{L})\end{array}$ & $\begin{array}{c}\mathrm{Mg} \\
(\mathrm{mg} / \mathrm{L})\end{array}$ & $\begin{array}{c}\mathrm{Na} \\
(\mathrm{mg} / \mathrm{L})\end{array}$ \\
\hline \multirow[t]{3}{*}{1} & \multirow[t]{3}{*}{05340540} & \multirow{3}{*}{$\begin{array}{l}\text { St. Croix River } \\
\text { above Rock } \\
\text { Island nr Fran- } \\
\text { conia, MN }\end{array}$} & Spring & $4 / 14 / 2015$ & 9:30 & 17.8 & 1.30 & 53.7 & 33.7 & 18.0 & 5.31 & 3.59 \\
\hline & & & Summer & $7 / 21 / 2015$ & 9:00 & 20.0 & 1.29 & 90.7 & 39.8 & 18.6 & 5.61 & 3.21 \\
\hline & & & Fall & $9 / 24 / 2015$ & $12: 10$ & 19.5 & 1.48 & 85.0 & 42.8 & 22.3 & 6.59 & 3.77 \\
\hline \multirow[t]{3}{*}{2} & \multirow[t]{3}{*}{05341550} & \multirow{3}{*}{$\begin{array}{l}\text { St. Croix River at } \\
\text { Stillwater, MN }\end{array}$} & Spring & $4 / 15 / 2015$ & $11: 00$ & 18.0 & 1.42 & 65.1 & 35.8 & 19.5 & 5.85 & 3.35 \\
\hline & & & Summer & $7 / 23 / 2015$ & $9: 15$ & 21.5 & 1.40 & 91.7 & 42.0 & 21.2 & 6.67 & 3.44 \\
\hline & & & Fall & $9 / 21 / 2015$ & $10: 05$ & 23.5 & 1.55 & 126 & 44.1 & 23.3 & 7.29 & 3.82 \\
\hline \multirow[t]{3}{*}{3} & \multirow[t]{3}{*}{05344490} & \multirow{3}{*}{$\begin{array}{l}\text { St. Croix River at } \\
\text { Prescott, WI }\end{array}$} & Spring & $4 / 21 / 2015$ & $9: 30$ & 15.9 & 1.58 & 31.6 & 37.8 & 22.6 & 7.50 & 3.68 \\
\hline & & & Summer & $7 / 22 / 2015$ & $11: 00$ & 17.5 & 1.74 & 25.3 & 39.9 & 21.6 & 7.17 & 3.63 \\
\hline & & & Fall & $9 / 22 / 2015$ & $11: 15$ & 19.9 & 1.67 & 103 & 41.6 & 23.4 & 7.81 & 3.90 \\
\hline \multirow[t]{3}{*}{4} & \multirow[t]{3}{*}{05288930} & \multirow{3}{*}{$\begin{array}{l}\text { Mississippi R. at } \\
\text { Franklin Ave. } \\
\text { in Minneapolis, } \\
\text { MN }\end{array}$} & Spring & $4 / 14 / 2015$ & 13:00 & 46.4 & 4.00 & 89.5 & 84.6 & 44.4 & 14.0 & 10.0 \\
\hline & & & Summer & $7 / 21 / 2015$ & $12: 15$ & 52.3 & 4.39 & 125 & 86.8 & 42.8 & 13.9 & 8.91 \\
\hline & & & Fall & $9 / 24 / 2015$ & $9: 05$ & 50.5 & 4.33 & 78.7 & 89.5 & 43.2 & 14.5 & 9.70 \\
\hline \multirow[t]{3}{*}{5} & \multirow[t]{3}{*}{05331580} & \multirow{3}{*}{$\begin{array}{l}\text { Mississippi River } \\
\text { below L\&D \#2 } \\
\text { at Hastings, } \\
\text { MN }\end{array}$} & Spring & $4 / 21 / 2015$ & $10: 15$ & 58.5 & 11.0 & 141 & 158 & 61.7 & 21.3 & 20.5 \\
\hline & & & Summer & $7 / 22 / 2015$ & $10: 15$ & 64.0 & 14.4 & 103 & 168 & 60.7 & 22.9 & 16.6 \\
\hline & & & Fall & $9 / 22 / 2015$ & 10:05 & 63.9 & 12.4 & 58.1 & 166 & 62.4 & 21.5 & 19.6 \\
\hline \multirow[t]{3}{*}{6} & \multirow[t]{3}{*}{05344980} & \multirow{3}{*}{$\begin{array}{l}\text { Mississippi River } \\
\text { below L\&D \#3 } \\
\text { near Red Wing, } \\
\text { MN }\end{array}$} & Spring & $4 / 13 / 2015$ & $11: 15$ & 38.0 & 7.33 & 105 & 104 & 43.3 & 15.6 & 14.6 \\
\hline & & & Summer & $7 / 20 / 2015$ & $10: 45$ & 53.2 & 11.5 & 120 & 139 & 51.6 & 19.1 & 13.2 \\
\hline & & & Fall & $9 / 23 / 2015$ & $10: 10$ & 47.6 & 8.62 & 113 & 118 & 46.7 & 16.2 & 13.2 \\
\hline \multirow[t]{3}{*}{7} & \multirow[t]{3}{*}{05330000} & \multirow{3}{*}{$\begin{array}{l}\text { Minnesota River } \\
\text { near Jordan, } \\
\text { MN }\end{array}$} & Spring & $3 / 25 / 2015$ & $17: 00$ & 54.7 & 33.6 & 34.7 & 339 & 90.6 & 42.8 & 21.8 \\
\hline & & & Summer & $7 / 30 / 2015$ & $15: 40$ & 78.2 & 27.9 & 119 & 289 & 89.4 & 35.5 & 14.7 \\
\hline & & & Fall & $9 / 18 / 2015$ & $10: 00$ & 77.1 & 28.2 & 52.8 & 316 & 96.9 & 35.5 & 15.5 \\
\hline \multirow[t]{3}{*}{8} & \multirow[t]{3}{*}{05369500} & \multirow{3}{*}{$\begin{array}{l}\text { Chippewa River at } \\
\text { Durand, WI }\end{array}$} & Spring & $3 / 31 / 2015$ & $10: 30$ & 13.8 & 0.678 & 34.4 & 30.4 & 14.6 & 5.19 & 3.90 \\
\hline & & & Summer & $7 / 28 / 2015$ & $11: 00$ & 16.3 & 0.703 & 86.6 & 36.4 & 16.7 & 6.03 & 3.83 \\
\hline & & & Fall & 9/29/2015 & $11: 00$ & 17.1 & 0.931 & 72.7 & 37.2 & 16.6 & 5.92 & 4.09 \\
\hline
\end{tabular}

was not collected using USGS protocols. Therefore, only one sample was collected, processed, and analyzed using USGS protocols, and plots presenting data collected from the Moose River using USGS protocols do not include error bars.

\section{Quality Assurance Comparisons}

Examination of quality assurance data (table 3.1 of appendix 3) indicated that laboratory methods for USGS protocols were accurate and environmental contamination of samples was minimal. Water samples were analyzed in 2015, and SRS results from spring and fall 2015 indicated that percent differences from known SRS values ranged from -3.55 percent to 5.11 percent (laboratory number 1 ; https://bqs.usgs.gov/; U.S. Geological Survey, 2017a).
Furthermore, Relative percent differences between replicate samples ranged from 0 to 22.5 percent, and 29 of the $30 \mathrm{cal}-$ culated relative percent differences were less than or equal to 4.95 percent. The single pair of replicate samples that had a relative percent difference of 22.5 percent were manganese samples with concentrations of 1.63 and 1.30 micrograms per liter $(\mu \mathrm{g} / \mathrm{L})$. Blank samples all had measured concentrations that were less than the published reporting limits (NWQL schedule 2701, lab codes 641 and 652; Fishman, 1993).

Examination of quality assurance data indicated that laboratory methods of research protocols were accurate and environmental contamination of samples was minimal. Water samples were analyzed in fall 2015, and SRS results from fall 2015 indicated that percent differences from known SRS values ranged from -4.20 percent to 10.60 percent (laboratory 
Table 2. Metal concentrations obtained using research protocols for stations in the five lakes and six major tributaries that compose the Namakan Reservoir system; map numbers reference stations shown in figure 1.

[no., number; Ba, barium; $\mu \mathrm{g} / \mathrm{L}$, microgram per liter; Li, lithium; Mn, manganese; Sr, strontium; Ca, calcium; mg/L, milligram per liter; Mg, magnesium; Na, sodium; MN, Minnesota; nr, near; Can, Canada; Rd., Road; Nat., National; For., Forest; Rd, Road; Co., County; SE, southeast; Isl., Island]

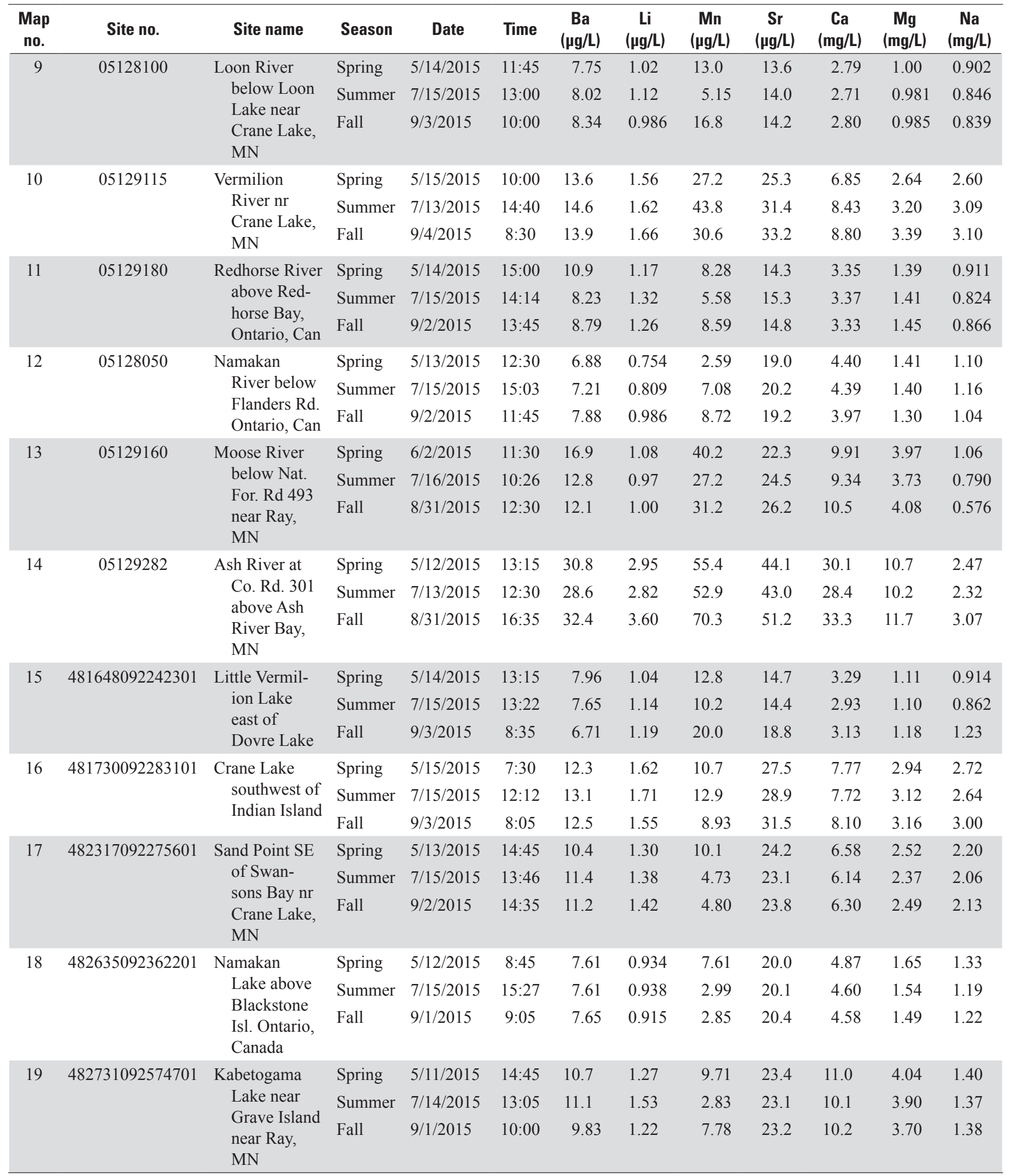


number 390; https://bqs.usgs.gov/; U.S. Geological Survey, 2017a). Furthermore, measured values were within 5 percent of known SRS values for all metals except lithium. Percent differences between measured metal concentrations and known values for the LFT3 standard were $2.3,4.5,-1.6,-4.5$, $4.2,-7.5$, and -6.5 percent for barium, lithium, manganese, strontium, calcium, magnesium, and sodium, respectively.

Replicate and blank samples also were analyzed to evaluate the quality of data obtained using research protocols (table 3.1 of appendix 3). Relative percent differences between replicate samples ranged from 0 to 10.4 percent among all metals other than manganese. Furthermore, for metals other than manganese, 34 of the 36 calculated relative percent differences were less than or equal to 4 percent. In contrast, relative percent differences for manganese ranged from 0.44 to 126 percent. However, analyses of SRS and LFT3 samples did not indicate an issue with the laboratory performance for manganese, and concentrations of individual metals measured in collected blank samples were negligible (appendix 3, table 3.1). Therefore, variability in measured manganese concentrations likely are attributed to factors other than laboratory techniques or quality assurance protocols.

Replicate and blank samples collected using research protocols were stored chilled for 6-33 weeks before filtration and analyses were completed. Particulate manganese forms colloidal complexes that are controlled by oxidation/reduction reactions, $\mathrm{pH}$, and time, but shape and size can affect how colloidal particles are filtered through 0.45-micron filters (Casale and others, 2002; Brandhuber and others, 2013), thus affecting measured manganese concentrations. Therefore, large measured differences in manganese concentrations between protocols and in replicate samples may be the result of the long holding time prior to filtration and analysis.

\section{Statistical Comparisons of Protocols}

Parametric statistical tests were used to assess differences between concentrations of metals measured using USGS and research protocols. Preliminary Shapiro-Wilk tests of the data and examination of plots from probability plot correlation coefficient tests indicated that some non-normality was evident, mainly modest skewness and heteroscedasticity. Several data transformations were examined; transformations did not make data normally distributed and did not change outcomes of statistical analyses. However, the parametric tests that were used are robust to modest departures from normality. Furthermore, based on the Central Limit Theorem, sample distribution of the mean can be assumed to be approximately normal when sample sizes are greater than 30 (Ott and Longnecker, 2010). Results of parametric tests were confirmed using equivalent nonparametric Wilcoxon signed rank tests. However, results of confirmatory nonparametric tests are not presented in this report.

Differences in metal concentrations analyzed using USGS and research protocols are presented in table 2.1 of appendix 2. Results of one-sample $t$-tests are presented in table 3; results were used to determine if the mean difference between concentrations obtained using different protocols was significantly different from zero for each compared constituent. Mean differences were significantly different for all constituents except $\mathrm{Sr}: \mathrm{Ca}$ (table 3). Although most measured

Table 3. Results of one-sample $t$-tests and 95-percent confidence intervals used to determine whether mean differences in results obtained using U.S. Geological Survey and research protocols were significantly different from zero.

[ $t$-statistic, value based on the student's $t$ distribution for the specified degrees of freedom; $p$-value, probability associated with $t$-statistic used in determining statistical significance; $\mu \mathrm{g} / \mathrm{L}$, microgram per liter; $<$, less than; $\mathrm{mg} / \mathrm{L}$, milligram per liter; $\mu \mathrm{mol} / \mathrm{mol}$; micromole per mole]

\begin{tabular}{lccccc}
\hline \multirow{2}{*}{ Constituent } & \multirow{2}{*}{$\boldsymbol{t}^{\mathbf{1}}$} & $\boldsymbol{p}$-value & \multicolumn{3}{c}{ Total difference $^{\mathbf{3}}$} \\
\cline { 4 - 6 } & & & Mean & 95-percent confidence interval & Units \\
\hline Barium (Ba) & 4.28 & 0.000 & 2.34 & $(1.23,3.44)$ & $\mu \mathrm{g} / \mathrm{L}$ \\
Manganese (Mn) & 5.28 & $<0.0001$ & 37.3 & $(23.0,51.6)$ & $\mu \mathrm{g} / \mathrm{L}$ \\
Strontium (Sr) & -6.99 & $<0.0001$ & -2.79 & $(-3.60,-1.98)$ & $\mu \mathrm{g} / \mathrm{L}$ \\
Calcium (Ca) & -3.13 & 0.003 & -0.972 & $(-1.60,-0.343)$ & $\mathrm{mg} / \mathrm{L}$ \\
Magnesium (Mg) & -7.82 & $<0.0001$ & -0.941 & $(-1.19,-0.697)$ & $\mathrm{mg} / \mathrm{L}$ \\
Sodium (Na) & -4.29 & 0.000 & -1.20 & $(-1.76,-0.631)$ & $\mathrm{mg} / \mathrm{L}$ \\
Ba:Ca & 8.74 & $<0.0001$ & 53.1 & $(40.8,65.4)$ & $\mu \mathrm{mol} / \mathrm{mol}$ \\
Sr:Ca & 1.38 & 0.177 & 23.3 & $(-10.9,57.5)$ & $\mu \mathrm{mol} / \mathrm{mol}$ \\
\hline
\end{tabular}

${ }^{1}$ Degrees of freedom $=38$ for all metals in table.

${ }^{2}$ Level of significance $(\alpha)=0.05$ for all analyses.

${ }^{3}$ Total difference $=($ research concentration - U.S. Geological Survey concentration $)$. 
results were significantly different between protocols, the 95-percent confidence intervals of mean total differences demonstrate that observed total differences were small relative to measured environmental values and that differences between protocols were consistent for individual metals other than manganese.

Absolute values were calculated for all percent difference results presented in table 2.1 of appendix 2 to further compare differences in results obtained using USGS and research protocols. Mean absolute percent differences with 95-percent confidence intervals (table 4) further demonstrate that except for manganese, metal results obtained using research protocols

Table 4. Absolute percent difference data used to compare metal results obtained using U.S. Geological Survey and research protocols.

\begin{tabular}{lcc}
\hline \multirow{2}{*}{ Constituent } & \multicolumn{2}{c}{ Absolute percent difference } \\
\cline { 2 - 3 } & Mean & 95-percent confidence interval \\
\hline Barium $(\mathrm{Ba})$ & 9.13 & $(6.31,12.0)$ \\
Manganese (Mn) & 1,530 & $(500,2550)$ \\
Strontium (Sr) & 5.97 & $(4.85,7.08)$ \\
Calcium (Ca) & 7.79 & $(6.35,9.24)$ \\
Magnesium (Mg) & 12.6 & $(11.7,13.6)$ \\
Sodium (Na) & 17.8 & $(16.0,19.6)$ \\
Ba:Ca & 15.9 & $(12.7,19.0)$ \\
Sr:Ca & 4.75 & $(3.15,6.36)$ \\
\hline
\end{tabular}

closely approximated metal results obtained using USGS protocols. Although results of one-sample $t$-tests presented in table 3 indicated that metal estimates were significantly different between the two protocols for all constituents except $\mathrm{Sr}: \mathrm{Ca}$, the 95-percent confidence intervals of total differences and absolute percent differences indicated that observed differences were small relative to measured environmental concentrations for all metals except manganese.

Results of simple linear regression analyses comparing metal concentrations obtained using USGS and research protocols indicated that relations were significant for all metals except manganese (table 5). Adjusted coefficients of determination $\left(R^{2}\right)$ for significantly different estimates indicated that 96.4 to 99.9 percent of the variability in concentrations obtained using USGS protocols can be explained by the linear relation with estimates from the research protocols (table 5; fig. 2). Regression equations were not used to develop predictive surrogates, and equations should not be considered valid for values of explanatory and response variables outside of the ranges of measured values presented in this report.

Total differences, absolute percent differences, and results of linear regression analyses demonstrate that the concentrations of manganese obtained using the research protocols described in this report are substantially different from concentrations obtained using USGS protocols. Furthermore, the pattern of differences between concentrations obtained using the two protocols was not consistent. The long holding times prior to filtration and analyses associated with samples collected using research protocols may have caused greater changes in manganese concentrations compared to other metals.

Table 5. Results of simple linear regression analyses used to determine whether relations between results obtained using U.S. Geological Survey and research protocols are significant.

[ $F$-statistic, ratio of variances used in determining statistical significance in regression analyses; $p$-value, probability value associated with $F$-statistic used to determine statistical significance; Adj. $R^{2}$, adjusted coefficient of determination; $\mu \mathrm{g} / \mathrm{L}$, microgram per liter; <, less than; USGS, U.S. Geological Survey; NA, not applicable; mg/L, milligram per liter; $\mu \mathrm{mol} / \mathrm{mol}$; micromole per mole]

\begin{tabular}{|c|c|c|c|c|c|}
\hline Constituent & Unit & F-statistic ${ }^{a}$ & $p$-value & Adj. $R^{2}$ & Equation \\
\hline Barium $(\mathrm{Ba})$ & $\mu \mathrm{g} / \mathrm{L}$ & 2,938 & $<0.0001$ & 0.987 & $\mathrm{Ba}_{\mathrm{USGS}}=0.835\left(\mathrm{Ba}_{\text {Research }}\right)+1.45$ \\
\hline Manganese (Mn) & $\mu \mathrm{g} / \mathrm{L}$ & 1.679 & 0.203 & 0.018 & $\mathrm{NA}$-relation not significant $\mathrm{t}^{\mathrm{b}}$ \\
\hline Strontium (Sr) & $\mu \mathrm{g} / \mathrm{L}$ & 37,460 & $<0.0001$ & 0.999 & $\mathrm{Sr}_{\mathrm{USGS}}=1.04\left(\mathrm{Sr}_{\text {Research }}\right)+0.521$ \\
\hline Calcium $(\mathrm{Ca})$ & $\mathrm{mg} / \mathrm{L}$ & 3,395 & $<0.0001$ & 0.989 & $\mathrm{Ca}_{\mathrm{USGS}}=0.992\left(\mathrm{Ca}_{\text {Research }}\right)+1.15$ \\
\hline Magnesium $(\mathrm{Mg})$ & $\mathrm{mg} / \mathrm{L}$ & 23,590 & $<0.0001$ & 0.998 & $\mathrm{Mg}_{\mathrm{USGS}}=1.11\left(\mathrm{Mg}_{\text {Research }}\right)+0.169$ \\
\hline Sodium $(\mathrm{Na})$ & $\mathrm{mg} / \mathrm{L}$ & 3,596 & $<0.0001$ & 0.990 & $\mathrm{Na}_{\text {USGS }}=1.29\left(\mathrm{Na}_{\text {Research }}\right)-0.240$ \\
\hline $\mathrm{Ba}: \mathrm{Ca}$ & $\mu \mathrm{mol} / \mathrm{mol}$ & 1,185 & $<0.0001$ & 0.969 & $\mathrm{Ba}: \mathrm{Ca}_{\mathrm{USGS}}=0.874\left(\mathrm{Ba}: \mathrm{Ca}_{\text {Research }}\right)-0.533$ \\
\hline $\mathrm{Sr}: \mathrm{Ca}$ & $\mu \mathrm{mol} / \mathrm{mol}$ & 1,033 & $<0.0001$ & 0.964 & $\mathrm{Sr}: \mathrm{Ca}_{\mathrm{USGS}}=0.920\left(\mathrm{Sr} \mathrm{Ca}_{\text {Research }}\right)+86.8$ \\
\hline
\end{tabular}

${ }^{a}$ Degrees of freedom for all $F$-statistics are $(1,37)$.

${ }^{\mathrm{b}} \mathrm{A}$ level of significance $(\alpha)$ of 0.05 was used to determine statistical significance. 

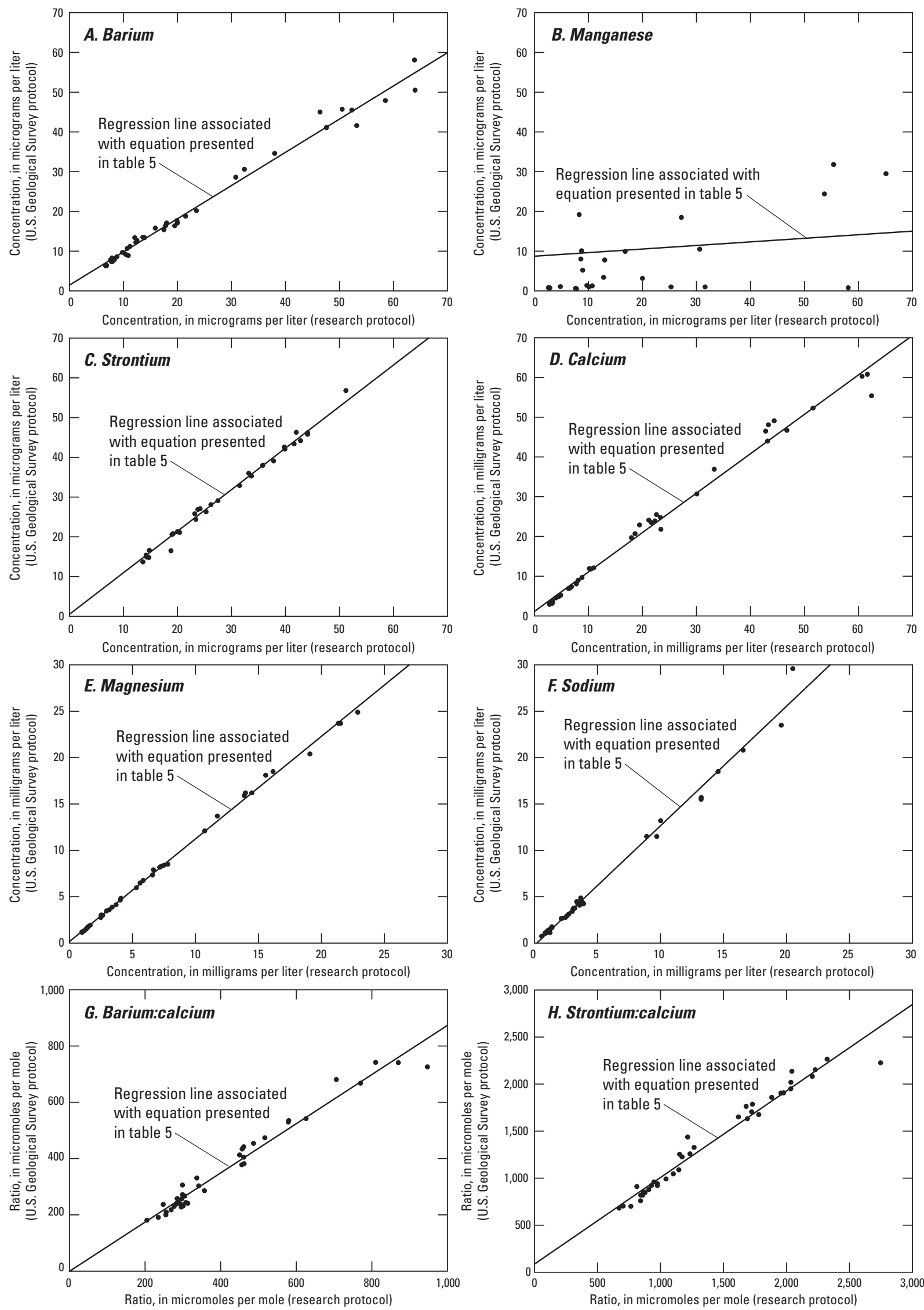

Figure 2. Scatterplots and trendlines from simple linear regression analyses comparing relations between results obtained using U.S. Geological Survey and research protocols. A, Barium. B, Manganese. C, Strontium. D, Calcium. E. Magnesium. F, Sodium. G, Barium:calcium. $H$, Strontium:calcium. 
Values of $\mathrm{Sr}: \mathrm{Ca}$ and $\mathrm{Ba}: \mathrm{Ca}$ obtained using USGS and research protocols were compared for each station (figs. 3 and 4) because $\mathrm{Sr}: \mathrm{Ca}$ and $\mathrm{Ba}: \mathrm{Ca}$ are commonly used in studies of fish migration (Elsdon and others, 2008, Phelps and others, 2012). In general, Sr:Ca values were similar between protocols for all stations in both study areas. Sand Point Lake southeast of Swansons Bay near Crane Lake, Minn. (USGS
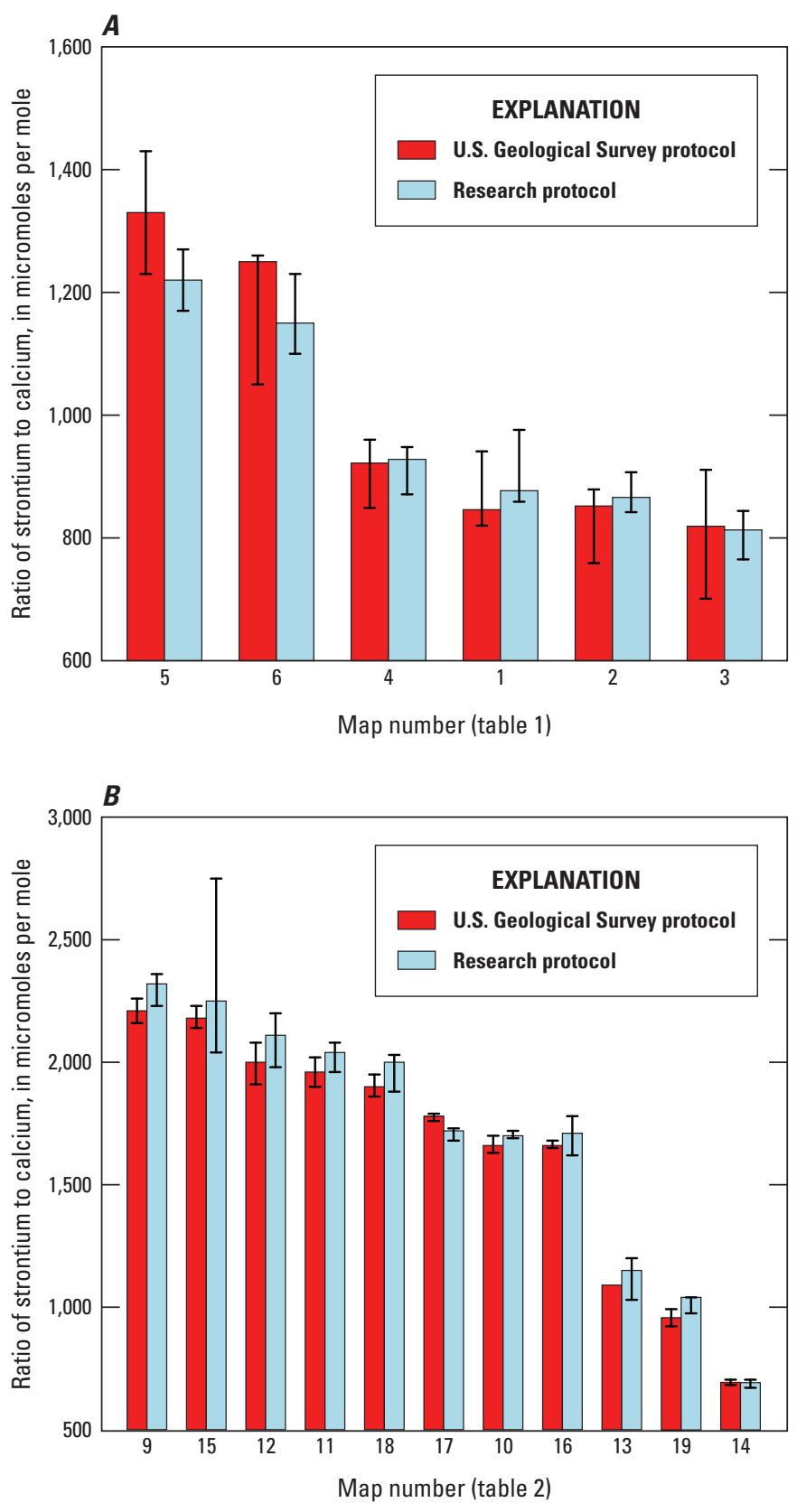

Figure 3. Median values and measured ranges for ratios of strontium to calcium (Sr:Ca) obtained using U.S. Geological Survey and research protocols for stations in $A$, the St. Croix National Scenic Riverway and Mississippi National River and Recreation Area study area (SACN-MISS); and $B$, the Voyageurs National Park study area (VOYA). station 482317092275601; map number 17, table 2, fig. 1) was the only station for which ranges of measured $\mathrm{Sr}$ :Ca values obtained using USGS (1,760-1,790 micromoles per mole) and research $(1,680-1,730$ micromoles per mole) protocols did not overlap (fig. $3 B$ ); however, in an ecological context, observed ranges were similar between protocols for Sand Point Lake. Finally, differences in $\mathrm{Sr}$ :Ca values among stations were similar between USGS and research protocols for both study areas (fig. 3), particularly when considered relative to measured concentrations for other stations in the VOYA study area.

Median Ba:Ca values were similar between protocols for all stations in both study areas, although less overlap was observed in measured Ba:Ca ranges (fig. 4) than in measured $\mathrm{Sr}$ :Ca ranges (fig. 3). Some differences in overlap of $\mathrm{Ba}: \mathrm{Ca}$ ranges between methods could result from summer samples not being collected using USGS protocols in the VOYA study area (fig. 4). Not having summer samples reduces the number of sample points and misses season-specific components of flow and weather conditions. Values of Ba:Ca obtained using research protocols were consistently higher than $\mathrm{Ba}: \mathrm{Ca}$ values obtained using USGS protocols for every station in the two study areas (fig. 4). However, differences in $\mathrm{Ba}$ :Ca values among stations were similar between protocols (fig. 4). Ranges of measured $\mathrm{Ba}$ :Ca values (fig. 4) were larger than ranges of measured Sr:Ca values (fig. 3) using both protocols, indicating that $\mathrm{Ba}: \mathrm{Ca}$ values may vary more with changing seasonal, flow, and weather conditions compared to $\mathrm{Sr}: \mathrm{Ca}$ values. Alternatively, $\mathrm{Ba}: \mathrm{Ca}$ values may be more susceptible than $\mathrm{Sr}: \mathrm{Ca}$ values to environmental contamination during sample collections or degradation caused by long holding times.

\section{Development of Metal Signatures}

This section of the report will be broken into three subsections. The first subsection compares commonly used metal signatures among stations within each study area. The second subsection compares data collected at stations in the SACNMISS study area during and prior to this study; only data collected using USGS protocols were compared in the second subsection. The third subsection provides insights for relating results of statistical analyses to studies involving chemical signatures used to demonstrate fish migrations.

\section{Metal Signatures Among Study Stations}

Median $\mathrm{Sr}: \mathrm{Ca}$ and $\mathrm{Ba}: \mathrm{Ca}$ values were plotted together to help further distinguish unique metal signatures for river stations in the two study areas (figs. 5 and 6). The Sr:Ca and $\mathrm{Ba}$ :Ca values obtained using USGS protocols for river stations in the two study areas are presented in figure 5. The $\mathrm{Sr}: \mathrm{Ca}$ and $\mathrm{Ba}: \mathrm{Ca}$ values obtained using research protocols for river stations in the two study areas are presented in figure 6 . The $\mathrm{Sr}: \mathrm{Ca}$ and $\mathrm{Ba}: \mathrm{Ca}$ values for stations on the Minnesota (map number 7) and Chippewa (map number 8) Rivers are included 

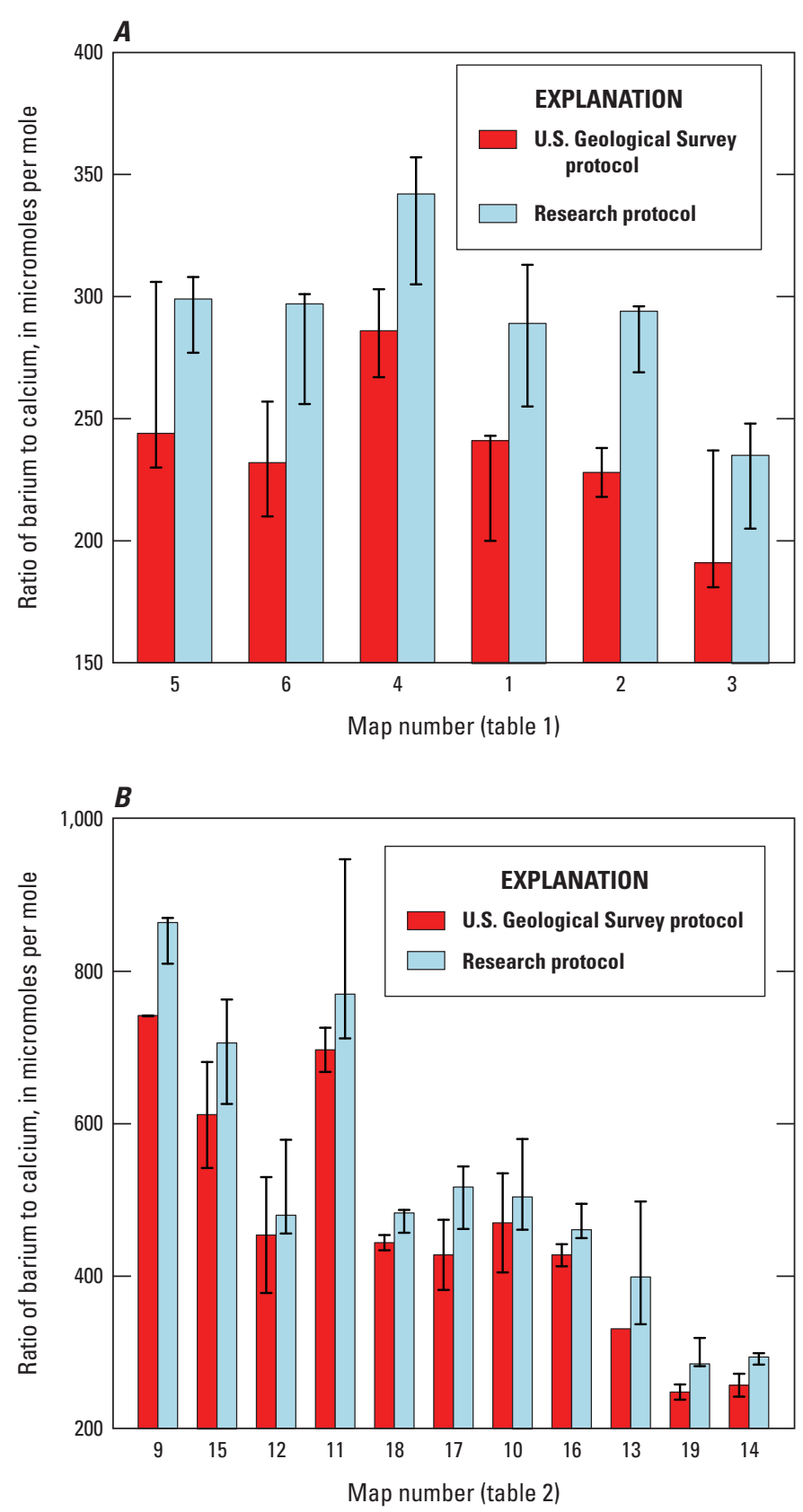

Figure 4. Median values and measured ranges for ratios of barium to calcium obtained using U.S. Geological Survey and research protocols for stations in $A$, the St. Croix National Scenic Riverway and Mississippi National River and Recreation Area study area (SACN-MISS); and $B$, the Voyageurs National Park study area (VOYA). in figure $6 \mathrm{~A}$. However, the Minnesota and Chippewa River stations were excluded from figure $5 A$ because only research protocols were used to collect water samples at these stations.

Lake stations from the VOYA study area were excluded from figures $5 B$ and $6 B$ for a few reasons. First, preservation and use of spawning habitat in rivers is the primary management concern for lake sturgeon in the VOYA study area, and excluding lake stations simplifies additional comparisons of river stations. Next, a large amount of overlap was observed among Sr:Ca and Ba:Ca values (figs. $3 B$ and $4 B$ ) for stations on Crane Lake (USGS station 481730092283101, map number 16, table 2, fig. 1), Sand Point Lake (map number 17), and Namakan Lake (USGS station 482635092362201, map number 18, table 2, fig. 1). Finally, $\mathrm{Sr}: \mathrm{Ca}$ and $\mathrm{Ba}: \mathrm{Ca}$ values were noticeably lower for Kabetogama Lake (USGS station 482731092574701, map number 19, table 2, fig. 1) compared to other lakes (figs. $3 B$ and $4 B$ ), and $\mathrm{Sr}: \mathrm{Ca}$ and $\mathrm{Ba}$ :Ca values generally were higher for Little Vermilion Lake (USGS station 481648092242301, map number 15, table 2, fig. 1) compared to other lakes (figs. $3 B$ and $4 B$ ).

Results presented in figure $5 A$ (USGS protocol) can be used to distinguish stations in the SACN-MISS study area. Median Sr:Ca values are similar for Mississippi River USGS stations 05331580 (map number 5, table 1, fig. 1) and 05344980 (map number 6, table 1, fig. 1). In contrast, the median Sr:Ca value for Mississippi River USGS station 05288930 (map number 4, table 1, fig. 1) is different from the median Sr:Ca values for stations 05331580 (map number 5) and 05344980 (map number 6) and similar to median $\mathrm{Sr}: \mathrm{Ca}$ values for St. Croix River USGS stations 05340540 (map number 1, table 1, fig. 1), 05341550 (map number 2, table 1, fig. 1), and 05344490 (map number 3, table 1, fig. 1). However, the Ba:Ca value for Mississippi River station 05288930 (map number 4) is higher than $\mathrm{Ba}: \mathrm{Ca}$ values for the three St. Croix River stations (map numbers 1-3). Therefore, Mississippi River station 05288930 (map number 4) can be distinguished from the other stations using a combination of $\mathrm{Sr}: \mathrm{Ca}$ and $\mathrm{Ba}: \mathrm{Ca}$ values measured using USGS protocols.

Results presented in figure $6 \mathrm{~A}$ (research protocol) were similar to results presented in figure $5 A$ (USGS protocol), but some differences were evident. First, figure $6 A$ includes $\mathrm{Sr}: \mathrm{Ca}$ and $\mathrm{Ba}: \mathrm{Ca}$ values for the Minnesota River near Jordan, Minn. (map number 7) and Chippewa River at Durand, Wis. (map number 8). Values of Sr:Ca at the Minnesota River station were distinguishably higher than $\mathrm{Sr}: \mathrm{Ca}$ values at other stations. Next, stations on the Chippewa (map number 8) and Mississippi (map number 4) Rivers could be distinguished from each other, but neither station could be distinguished from the St. Croix River station at Franconia (map number 1) based on Sr:Ca and Ba:Ca values. Mississippi River stations 05331580 (map number 5) and 05344980 (map number 6) had similar $\mathrm{Sr}: \mathrm{Ca}$ and $\mathrm{Ba}: \mathrm{Ca}$ values and can be distinguished from other stations using only $\mathrm{Sr}: \mathrm{Ca}$ values. Based on $\mathrm{Sr}: \mathrm{Ca}$ values, St. Croix River station 05341550 (map number 2) was not distinguishable from St. Croix River stations 05340540 or 05344490 (map numbers 1 and 3, respectively), but stations 

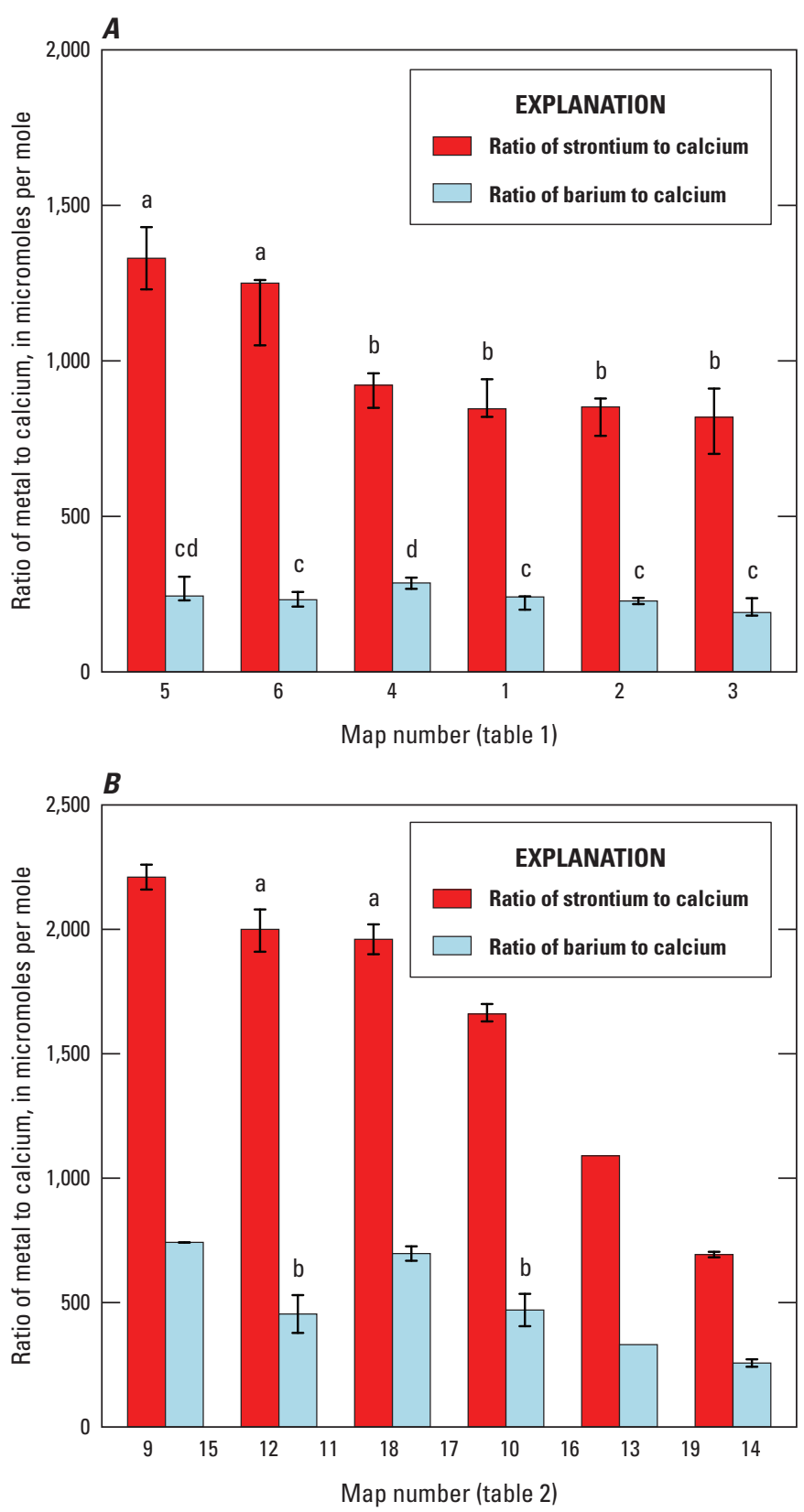

Figure 5. Median values and measured ranges for ratios of strontium to calcium (Sr:Ca) and barium to calcium (Ba:Ca) obtained using U.S. Geological Survey protocols for stations in $A$, the St. Croix National Scenic Riverway and Mississippi National River and Recreation Area study area (SACN-MISS); and $B$, the Voyageurs National Park study area (VOYA); similar letters above graph bars indicate that ranges of measured values overlap among stations.
05340540 (map number 1) and 05344490 (map number 3) were distinguishable from each other. Based on $\mathrm{Ba}: \mathrm{Ca}$ values, St. Croix River station 05340540 (map number 1) was not distinguishable from station 05341550 (map number 2) or station 05344490 (map number 3), but stations 05341550 (map number 2) and 05344490 (map number 3) were distinguishable from each other.

St. Croix River station 05340540 (map number 1) could not be distinguished from Mississippi River station 05288930 (map number 4) or Chippewa River station 05369500 (map number 8) using measured ranges of $\mathrm{Sr}: \mathrm{Ca}$ and $\mathrm{Ba}: \mathrm{Ca}$ obtained using research protocols (fig. $6 A$ ). However, collecting and analyzing additional samples could reduce variability and help to further distinguish metal signatures among these stations because differences in median $\mathrm{Sr}: \mathrm{Ca}$ and $\mathrm{Ba}: \mathrm{Ca}$ values were similar among stations regardless of protocol used. Furthermore, migratory fish would have to cross stations that can be distinguished using $\mathrm{Sr}: \mathrm{Ca}$ and $\mathrm{Ba}: \mathrm{Ca}$ values (St. Croix River stations 05341550 and 05344490 , map numbers 2 and 3; Mississippi River stations 05331580 and 05344980 , map numbers 4 and 5) to reach stations that cannot be distinguished. Therefore, capture location of the fish and available fish telemetry data could be used in conjunction with concentrations of metals in water to develop statistical relations between concentrations of metals measured in water and in cross sections of fish bony structures.

Measured $\mathrm{Sr}: \mathrm{Ca}$ and $\mathrm{Ba}: \mathrm{Ca}$ values obtained using USGS (fig. $5 B$ ) and research (fig. $6 B$ ) protocols can be used interchangeably to distinguish river stations in the VOYA study area. The Loon (USGS station 05128100, map number 9, table 2, fig. 1), Vermilion (USGS station 05129115, map number 10, table 2, fig. 1), Moose (USGS station 05129160, map number 13, table 2, fig. 1), and Ash (USGS station 05129282, map number 14, table 2, fig. 1) Rivers can be distinguished using only Sr:Ca values (figs. $5 A$ and $6 A$ ). In contrast, $\mathrm{Sr}: \mathrm{Ca}$ values were indistinguishable for the Namakan (USGS station 05128050, map number 12, table 2, fig. 1) and Redhorse (USGS station 05129180, map number 11, table 2, fig. 1) Rivers, which makes sense given the geographic proximities and similar underlying geologic formations of the two rivers (Day and others, 1990; Woodruff and others, 2002). However, $\mathrm{Ba}: \mathrm{Ca}$ values were distinguishably lower for the Namakan River (map number 12) compared to the Redhorse River (map number 11) using both protocols.

Among river stations in the VOYA study area, variability in $\mathrm{Ba}$ :Ca values was higher using research protocols than using USGS protocols, causing slight differences in which stations had overlapping $\mathrm{Ba}$ :Ca ranges (figs. $5 B$ and $6 B$ ). However, general patterns of mean $\mathrm{Ba}: \mathrm{Ca}$ values among stations were similar between protocols (figs. $5 B$ and $6 B$ ). As a result, differences in measured $\mathrm{Ba}: \mathrm{Ca}$ ranges between protocols did not change the manner in which stations could be distinguished when using a combination of $\mathrm{Sr}: \mathrm{Ca}$ and $\mathrm{Ba}: \mathrm{Ca}$ values (figs. $5 B$ and $6 B$ ). 

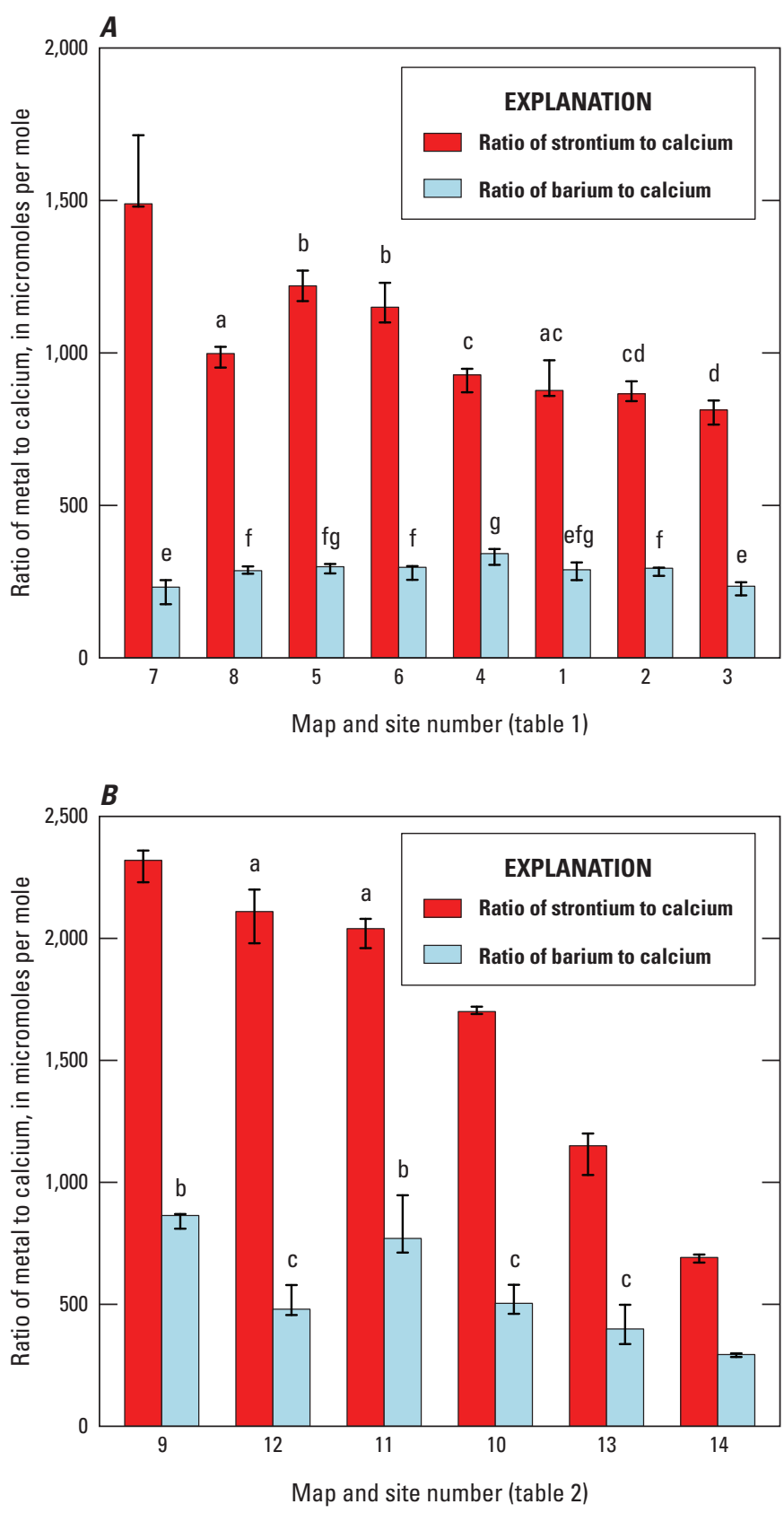

Figure 6. Median values and measured ranges for ratios of strontium to calcium (Sr:Ca) and barium to calcium (Ba:Ca) obtained using research protocols for stations in $A$, the St. Croix National Scenic Riverway and Mississippi National River and Recreation Area study area (SACN-MISS); and $B$, the Voyageurs National Park study area (VOYA); similar letters above graph bars indicate that ranges of measured values overlap among stations.
In general, rivers compared within each study area were more easily distinguished using data obtained from USGS protocols than from data obtained using research protocols (figs. 5 and 6). For example, station 05288930 (map number 4) on the Mississippi River and station 05340540 (map number 1) on the St. Croix River could be distinguished using a combination of $\mathrm{Sr}: \mathrm{Ca}$ and $\mathrm{Ba}: \mathrm{Ca}$ data obtained from USGS protocols but could not be distinguished from each other using data obtained from research protocols. Furthermore, $\mathrm{Sr}: \mathrm{Ca}$ and $\mathrm{Ba}$ :Ca relations among stations within the St. Croix River were slightly different depending on the protocol used. However, a combination of $\mathrm{Sr}: \mathrm{Ca}$ and $\mathrm{Ba}: \mathrm{Ca}$ values still can be used to develop different signatures among adjacent stations, regardless of the protocol used, and additional samples likely would help further evaluate differences in results obtained using different protocols. Although each protocol has caveats to consider, either protocol seems to produce results that can be used to distinguish river stations that are important for studies of fish migratory histories.

\section{Comparisons to Previously Collected Metal Concentration Data}

Concentrations of calcium, barium, and strontium measured in samples collected using USGS protocols prior to this study were compared to concentrations measured during this study for the stations on the Mississippi and St. Croix Rivers (U.S. Geological Survey, 2017b). Data from individual stations were pooled by river because few data points were available prior to this study. In the Mississippi River, ranges of calcium (49.0 to 69.0 milligrams per liter [mg/L]), barium (44.0 to $65.0 \mu \mathrm{g} / \mathrm{L})$, and strontium (109 to $210 \mu \mathrm{g} / \mathrm{L}$ ) measured from 1995 through 2012 overlapped with ranges of calcium (44.0 to $60.8 \mathrm{mg} / \mathrm{L}$ ), barium (34.6 to $50.5 \mu \mathrm{g} / \mathrm{L}$ ), and strontium $(91.1$ to $175 \mu \mathrm{g} / \mathrm{L}$ ) measured during this study. In the St. Croix River, previous barium and strontium data were not available from 1995 through 2012. However, the range of calcium (14.5 to $26.1 \mathrm{mg} / \mathrm{L}$ ) measured from 1995 through 2012 overlapped with the range of calcium (19.7 to $25.5 \mathrm{mg} / \mathrm{L}$ ) measured during this study. Collectively, these comparisons indicate that concentrations of strontium, barium, and calcium in the Mississippi and St. Croix Rivers are somewhat stable during a period of 3 to 20 years and should be suitable for studying long-lived, migratory fishes. 


\section{Insights from Method and Station Comparisons}

Collectively, statistical analyses indicate that the research protocols outlined in this report provide metal concentration data that generally are comparable to data obtained using USGS protocols, particularly for commonly used $\mathrm{Sr}: \mathrm{Ca}$ values. Results presented in this report likely are broadly applicable over large regions because the two study areas have drastically different water chemistries, underlying geologies, and hydrologic settings. Presented metal concentrations can be used to further characterize water chemistries of the VOYA study area and evaluate how changes in weather, land use, and hydrology are affecting water chemistries in the Namakan Reservoir system. Metals data presented in this study previously were unavailable for the Namakan Reservoir system.

For individual metals other than manganese, differences between concentrations obtained using USGS protocols and research protocols were consistent across all field stations (table 3). Therefore, studies using a single protocol to compare metal concentrations across several field stations likely would obtain similar differences in station-specific metal signatures regardless of the protocol that was used. In addition, mean absolute percent differences for strontium (5.97 percent), calcium ( 7.79 percent), and barium (9.13 percent) were all less than 10 percent (table 4 ), and these metals are the most commonly used metals for studies involving the use of metal signatures to demonstrate fish migrations (Crook and Gillanders, 2006; Elsdon and Gillanders, 2006; Elsdon and others, 2008; Humston and others, 2010; Smith and Whitledge, 2010; Hayden and others, 2011; Phelps and others, 2012).

Manganese was the only metal for which USGS and research protocols did not produce comparable results. Results of statistical analyses indicate that research protocols used in this study are not suitable for measuring manganese. Shiller (2003) noted large decreases in manganese concentrations related to aeration of water following ice-out. Shiller (2003) also noted the effects of suspended particulate material on the partitioning of dissolved and particulate manganese concentrations. Additional studies would be required to determine if a shorter holding time prior to filtration would result in more comparable manganese concentrations between USGS and research protocols.

Lithium concentrations were measured for samples collected, processed, and analyzed using research protocols (tables 1 and 2); however, lithium concentrations were not measured in samples collected and analyzed using USGS protocols. Therefore, lithium concentration estimates obtained using the two protocols cannot be compared, and the quality of lithium data obtained using research protocols only can be evaluated using replicates and standard reference materials. Five-year historical laboratory performance data for the laboratory at USM indicate some quality control issues for lithium analyses (-26.10 to 46.10 percent) in 2016 (U.S. Geological Survey, 2017c). However, collected water samples were analyzed in fall 2015, and the measured lithium value for fall 2015 was within 10.6 percent of the known SRS value
(U.S. Geological Survey, 2017c). Additional studies that include an NWQL schedule for lithium in the USGS protocol would be required to determine how closely lithium concentrations obtained using the research protocols approximate lithium concentrations obtained using USGS protocols.

Shorter holding times prior to filtration likely would improve the quality of metal concentrations obtained using research protocols (Fishman, 1993; Shiller, 2003). Furthermore, immediate filtration of collected samples may increase the time samples can be held prior to analysis before substantial changes in data quality occur. Finally, increasing the number of samples analyzed for each station likely would improve abilities to distinguish stations using $\mathrm{Sr}: \mathrm{Ca}$ and $\mathrm{Ba}: \mathrm{Ca}$ values. However, confirmations of hypotheses presented in this paragraph are beyond the scope of this report.

Research protocols are simpler and require less specialized equipment and training compared to USGS protocols. Therefore, the ability to determine metal signatures for several study sites using simpler procedures might facilitate future studies focused on fish migrations. Sampling costs may be reduced because grab samples can be collected quickly and easily without specialized training or equipment. Reduced costs and increased ease of sampling could facilitate sampling more stations within the study areas, including mouths of tributary streams that may provide important feeding and resting areas for juvenile lake sturgeon (Peterson and others, 2007). Also, if fish are difficult to capture consistently, fisheries crews can collect a grab water sample at locations where they successfully capture the target species. Fisheries crews could filter and store chilled samples until acquiring enough samples to ship a large batch for analysis. Furthermore, having water samples that are paired in space and time with collected bony fish structures would maximize the utility of ongoing fisheries surveys, increase efficiency of developing metal signatures for connected water bodies, and provide opportunities to address additional fisheries management issues.

\section{Limitations of the Study}

There are limitations to consider when using the study results presented in this report. First, holding times prior to filtration and analyses of water samples were not consistent between the compared protocols. Observed differences in results obtained using the two protocols may have been reduced by using similar holding times. Although results were significantly different between protocols for all constituents except $\mathrm{Sr}: \mathrm{Ca}$, total differences in results were small for all constituents except manganese (table 3). Manganese concentrations were significantly different between protocols, and differences in manganese concentrations between protocols were not consistent among stations. Therefore, manganese concentrations obtained using research protocols should not be considered valid without further study. 
Next, study results presented in this report cannot be used to determine whether observed differences are attributed to field collection methods, sample holding times prior to filtration, or laboratory analysis methods. Additional studies could be designed to determine the sources and magnitudes of differences by creating a sample matrix that incorporates all possible combinations of field collection methods, sample holding times, and laboratory analysis methods. Furthermore, evaluations and conclusions related to protocol comparisons cannot be extended to other metals that were not compared in this study.

Finally, results presented in this report are based on small sample sizes from two pilot studies. Additional samples likely would help refine results of statistical analyses and account for a higher proportion of spatial and temporal variability related to season, flow, water level, localized weather conditions, and annual wet/dry cycles. Therefore, sample sizes and statistical techniques should be considered carefully when using information presented in this report to inform decisions about management of natural resources.

\section{Summary}

Signatures can be developed from metal concentrations in water and fish bony structures, and these metal signatures can be used to demonstrate migration of individual fish between connected water bodies. U.S. Geological Survey (USGS) protocols for collecting water samples represent the entire stream cross section, but USGS protocols are time and labor intensive and require specialized training and equipment. Therefore, researchers often use single grab samples at the water surface and simpler protocols for filtration and analysis to characterize metal concentrations in rivers for use in studies of fish migration. Unfortunately, comparisons between metal concentrations obtained using USGS and research protocols were lacking.

This report was prepared by the USGS in cooperation with the National Park Service and the Missouri Department of Conservation. The purposes of this report were to (1) provide metal concentration data that did not previously exist for waters of Namakan Reservoir system, (2) compare metal concentrations obtained using two different protocols, and (3) compare commonly used metal signatures among stations in two different study areas.

In 2015, paired seasonal water samples were collected using USGS and research protocols for two study areas spanning three different National Park Service units. Metals compared between USGS and research protocols include barium, calcium, magnesium, manganese, sodium, and strontium. In addition, statistical analyses were conducted on ratios of barium to calcium $(\mathrm{Ba}: \mathrm{Ca})$ and strontium to calcium $(\mathrm{Sr}: \mathrm{Ca})$ in collected water samples. Concentrations and ratios obtained using USGS and research protocols were compared using (1) one-sample $t$-tests on the total concentration differences,
(2) percent differences of concentrations obtained using USGS and research protocols, and (3) simple linear regression analyses. Graphical plots of median values and measured ranges were used to compare ratios of strontium to calcium $(\mathrm{Sr}: \mathrm{Ca})$ and barium to calcium (Ba:Ca) obtained using different protocols among individual stations within the two study areas. For stations on the Mississippi and St. Croix Rivers, ranges in concentrations of calcium, barium, and strontium obtained using USGS protocols were compared between samples collected from 1995 through 2012 and samples collected in this study. Comparisons were used to evaluate the long-term stability of metal concentrations in the study area.

Collectively, results presented in this report demonstrated that research protocols provided metal concentration data that generally were similar to data obtained using USGS protocols for all compared metals except manganese. Holding times of 6-33 weeks prior to filtration and analyses for samples collected using research protocols may have caused greater changes in manganese concentrations compared to other metals. Strontium, barium, and calcium are the metals most commonly used in studies of fish migration, and concentrations of these metals were similar using different protocols. However, rivers within each study area were more easily distinguished from each other using metal concentration data obtained using USGS protocols compared to data obtained using research protocols. Information presented in this report can be used to develop studies that use identified metal signatures in connected water bodies and bony fish structures to demonstrate fish migration.

\section{References Cited}

Brandhuber, P., Clark, S., Knocke, W., and Tobiason, J., 2013, Guidance for the treatment of manganese: Denver, Colorado, Water Research Foundation, 37 p. [Also available at http://www.waterrf.org/resources/webcasts/Lists/Webcasts/ Attachments/82/4373_Manganese_Webcast_June_4.pdf.]

Casale, R.J., LeChevallier, M.W., and Pontius, F.W., 2002, Manganese control and related issues: Denver, Colorado, American Water Works Research Foundation and American Water Works Association, $187 \mathrm{p}$.

Crook, D.A., and Gillanders, B.M., 2006, Use of otolith chemical signatures to estimate carp recruitment sources in the mid-Murray River: Australia River Research and Applications, v. 22, no. 8, p. 871-879. [Also available at https://doi.org/10.1002/rra.941.]

Day, W.C., Southwick, D.L., Schulz, K.J., and Klein, T.L., 1990, Bedrock geologic map of the International Falls 1 degree by 2 degrees Quadrangle, Minnesota, United States and Ontario, Canada: U.S. Geological Survey Miscellaneous Investigations Series Map 1965-B. [Also available at https://pubs.er.usgs.gov/publication/i1965B.] 
Elsdon, T.S., and Gillanders, B.M., 2006, Identifying migratory contingents of fish by combining otolith $\mathrm{Sr}$ :Ca with temporal collections of ambient $\mathrm{Sr}$ :Ca concentrations: Journal of Fish Biology, v. 69, no. 3, p. 643-657. [Also available at https://doi.org/10.1111/j.1095-8649.2006.01136.x.]

Elsdon, T.S., Wells, B.K., Campana, S.E., Gillanders, B.M., Jones, C.M., Limburg, K.E., Secor, D.H., Thorrold, S.R., and Walther, B.D., 2008, Otolith chemistry to describe movements and life-history parameters of fishes-Hypotheses, assumptions, limitations, and inferences: Oceanography and Marine Biology-An Annual Review, v. 46, p. 297-330. [Also available at https://doi.org/10.1201/9781420065756.ch7.]

Fishman, M.J., ed., 1993, Methods of analysis by the U.S. Geological Survey National Water Quality Laboratory-Determination of inorganic and organic constituents in water and fluvial sediments: U.S. Geological Survey Open-File Report 93-125, 217 p.

Hayden, T.A., Miner, J.G., Farver, J.R., and Fryer, B.J., 2011, Philopatry and vagrancy of white bass (Morone chrysops) spawning in the Sandusky River-Evidence of metapopulation structure in western Lake Erie using otolith chemistry: Journal of Great Lakes Research, v. 37, no. 4, p. 691-697. [Also available at https://doi.org/10.1016/j.jglr.2011.08.012.]

Humston, R., Priest, B.M., Hamilton, W.C., and Bugas, P.E., Jr., 2010, Dispersal between tributary and main-stem rivers by juvenile smallmouth bass evaluated using otolith microchemistry: Transactions of the American Fisheries Society, v. 139, no. 1, p. 171-184. [Also available at https://doi.org/10.1577/T08-192.1.]

Kallemeyn, L.W., Holmberg, K.L., Perry, J.A., and Odde, B.Y., 2003, Aquatic synthesis for Voyageurs National Park: U.S. Geological Survey Information and Technology Report 2003-0001, 96 p. [Also available at https://pubs.er.usgs.gov/publication/itr030001.]

Lorenz, D.L., 2014, smwrStats-R functions to support statistical methods in water resources: U.S. Geological Survey R Archive Network. [Also available at https://github.com/ USGS-R/smwrStats/.]

Lorenz, D.L., and Diekoff, A.L., 2017, smwrGraphs-An $\mathrm{R}$ package for graphing hydrologic data, version 1.1.2: U.S. Geological Survey Open-File Report 2016-1188, 17 p., accessed November 2017 at https:/doi.org/10.3133/ ofr20161188. [Supersedes USGS Open-File Report 20151202.]
Mueller, D.S., Wagner, C.R., Rehmel, M.S., Oberg, K.A., and Rainville, F., 2013, Measuring discharge with acoustic Doppler current profilers from a moving boat (ver. 2.0, December 2013): U.S. Geological Survey Techniques and Methods, book 3, chap. A22, 95 p. [Also available at http://pubs.water.usgs.gov/tm3a22.]

Ott, R.L., and Longnecker, M.T., 2010, An introduction to statistical methods and data analysis (6th ed.): Brooks/Cole, Cengage Learning, 1296 p.

Peterson, D.L., Vecsei, P., and Jennings, C.A., 2007, Ecology and biology of the lake sturgeon-A synthesis of current knowledge of a threatened North American Acipenseridae: Reviews in Fish Biology and Fisheries, v. 17, no. 1, p. 59-76. [Also available at https://doi.org/10.1007/ s11160-006-9018-6.]

Phelps, Q.E., Whitledge, G.W., Tripp, S.J., Smith, K.T., Garvey, J.E., Herzog, D.P., Ostendorf, D.E., Ridings, J.W., Crites, J.W., Hrabik, R.A., Doyle, W.J., and Hill, T.D., 2012, Identifying river of origin for age-0 Scaphirhynchus sturgeons in the Missouri and Mississippi Rivers using fin ray microchemistry: Canadian Journal of Fisheries and Aquatic Sciences, v. 69, no. 5, p. 930-941. [Also available at https://doi.org/10.1139/f2012-038.]

Shaw, S.L., 2010, Lake sturgeon (Acipenser fulvescens) population attributes, reproductive structure, and distribution in Namakan Reservoir, Minnesota and Ontario: M.S. Thesis, South Dakota State University, 110 p.

Shaw, S.L., Chipps, S.R., Windels, S.K., Webb, M.A.H., and McLeod, D.T., 2013, Influence of sex and reproductive status on seasonal movement of lake sturgeon in Namakan Reservoir, Minnesota-Ontario: Transactions of the American Fisheries Society, v. 142, no. 1, p. 10-20. [Also available at https://doi.org/10.1080/00028487.2012.720625.]

Shaw, S.L., Chipps, S.R., Windels, S.K., Webb, M.A.H., McLeod, D.T., and Willis, D.W., 2012, Lake sturgeon population attributes and reproductive structure in the Namakan Reservoir, Minnesota and Ontario: Journal of Applied Ichthyology, v. 28, no. 2, p. 168-175. [Also available at https://doi.org/10.1111/j.1439-0426.2011.01927.x.]

Shiller, A.M., 2003, Syringe filtration methods for examining dissolved and colloidal trace element distributions in remote field locations: Environmental Science \& Technology, v. 37, no. 17, p. 3953-3957. [Also available at https://doi.org/10.1021/es0341182.]

Smith, K.T., and Whitledge, G.W., 2010, Fin ray chemistry as a potential natural tag for smallmouth bass in northern Illinois rivers: Journal of Freshwater Ecology, v. 25, no. 4, p. 627-635. [Also available at https://doi.org/10.1080/0270 5060.2010.9664412.] 
U.S. Geological Survey, variously dated, The national field manual for the collection of water-quality data (version 7): U.S. Geological Survey Techniques and Methods, book 9, chaps. A1-A10, accessed April 5, 2015, at http://pubs.water.usgs.gov/twri9A.

U.S. Geological Survey, 2017a, Quality Systems Branch -Web interface: accessed May 31, 2017, at https://bqs.usgs.gov/.

U.S. Geological Survey, 2017b, National Water Information System-Web interface: accessed June 3, 2017, at https://doi.org/10.5066/F7P55KJN.

U.S. Geological Survey, 2017c, Inter-laboratory comparison study results: U.S. Geological Survey Office of Water Quality Branch of Quality Systems, accessed December 12, 2017, at https://bqs.usgs.gov/srs_study/reports/index.php.

Venables, W.N., Smith, D.M., and the R Development Core Team, 2010, An introduction to R: Bristol, Network Theory Ltd., $100 \mathrm{p}$.

Woodruff, L.G., Cannon, W.F., Dicken, C.L., and Pimley, S., 2002, Bedrock and soil geochemistry from Voyageurs National Park, Minnesota: U.S. Geological Survey Open-File Report 2002-196, 8 p. [Also available at https://pubs.er.usgs.gov/publication/ofr02196.] 


\section{Appendix 1. R coding and Data Files Used in Analyses}

Appendix 1 files are available online at https://doi.org/10.3133/sir21085143.

The file "Rcoding.pdf" contains the R code used in the presented statistical analyses. Additional notes that clarify the steps of the analyses are included in green text. Original comma-separated value (csv) files used to import data into R for analyses also are included.

The file "differencedata.csv" provides data used to produce results of one-sample $t$-tests presented in table 3. The column titled "mapno" represents the map number associated with sites presented in figure 1 and tables 1 and 2. The column titled "date" represents the date of sample collection. Remaining columns describe differences in measured metal concentrations between research and U.S. Geological Survey protocols, presented as research concentration minus U.S. Geological Survey concentration. Difference data are provided for the following constituents: barium (Ba), manganese (Mn), strontium (Sr), calcium $(\mathrm{Ca})$, magnesium $(\mathrm{Mg})$, sodium $(\mathrm{Na})$, and ratios of barium to calcium $(\mathrm{BaCa})$ and strontium to calcium $(\mathrm{SrCa})$.

The file "SLRdata.csv" provides data used to produce results of simple linear regression analyses presented in figure 2 and table 5. The column titled "mapno" represents the map number associated with sites presented in figure 1 and tables 1 and 2. The column titled "date" represents the date of sample collection. Remaining columns describe water concentration data for the following metals: barium (Ba), manganese (Mn), strontium ( $\mathrm{Sr}$ ), calcium $(\mathrm{Ca})$, magnesium $(\mathrm{Mg})$, sodium $(\mathrm{Na})$, and ratios of barium to calcium $(\mathrm{BaCa})$ and strontium to calcium $(\mathrm{SrCa})$. Column headings with a "U" included after the metal abbreviation represent concentrations obtained using U.S. Geological Survey protocols. Column headings with an "R" included after the metal abbreviation represent concentrations obtained using research protocols.

\section{Appendix 2. Comparisons of Individual Data Pairs}

Appendix 2 (available online at https://doi.org/10.3133/sir21085143) provides paired metals data obtained using U.S. Geological Survey and research protocols. In addition, differences and percent differences are presented for individual data pairs to further compare results obtained using the two protocols.

Table 2.1. Differences and percent differences for paired data obtained using U.S. Geological Survey and research protocols.

\section{Appendix 3. Quality Assurance Data}

Appendix 3 (available online at https://doi.org/10.3133/sir21085143) provides information about blank and replicate samples used in quality assurance of U.S. Geological Survey and research protocols presented in this report. Quality assurance data are provided for barium, lithium, manganese, strontium, calcium, magnesium, and sodium.

Table 3.1. Blank and replicate quality assurance data for metal concentrations obtained using U.S. Geological Survey and research protocols. 
For more information about this publication, contact: Director, USGS Upper Midwest Water Science Center 2280 Woodale Drive

Mounds View, MN 55112

763-783-3100

For additional information, visit: https://mn.water.usgs.gov

Publishing support provided by the

Rolla Publishing Service Center 


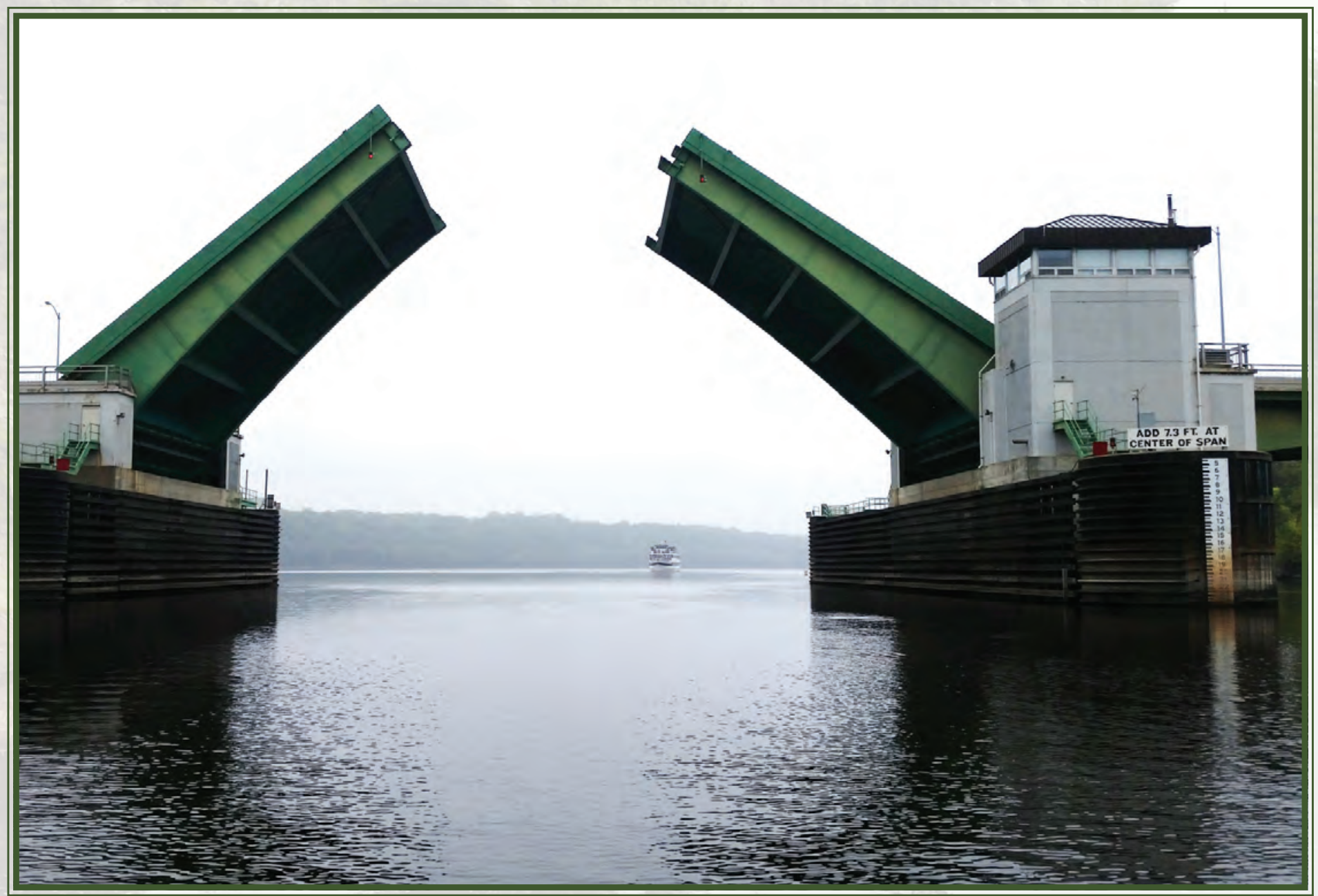

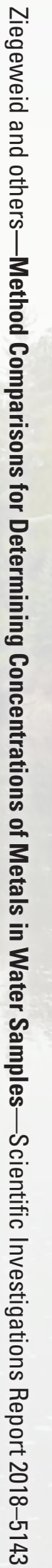

